\title{
VERORDENINGEN AANGAANDE DE ADAT DER INLANDSCHE CHRISTENEN OP HET EILAND HALMAHERA.
}

(Zooals die vastgesteld zijn door de Christen-Hoofden en Oudsten der districten Tobèlo, Galéla, Kau, Sidangoli en Loda).

Bewerkt en van Aanteekeningen voorzien

DOOR

A. HUETING,

Zendeling der Utrechtsche Zendings-Vereeniging.

Toen de Christelijke zending in de in hoofde dezes genoemde districten vasten voet verkregen had, kwam uit den aard der zaak de nieuwe toestand veelvuldig in botsing met de heidensche adat. Het was nu de takk der zending, ordenend en regelend op te treden. In al de districten, waar het Christendom wortel had geschoten, riep zij daartoe hoofden en oudsten bijeen, en legde dezen de vraag voor, wat voortaan als adat gelden moest.

De besprekingen waren dikwijls heftig, maar men kwam toch tot een resultaat. Op de eerste bijeenkomst volgde eene tweede, op de tweede eene derde, en er zullen waarschijnlijk nog wel meer volgen. De ontwikkeling van het volk schept nieuwe verhoudingen, het doorwerkend Christendom nieuwe gevoelens; beide hebben een wijzigenden invloed op de adat, en daarmede moet voortdurend rekening worden gehouden.

Intusschen geven wij hier, met eenige toelichtingen, de verordeningen zooals die thans zijn vastgesteld.

\section{HOOFDSTUK I.}

\section{A. DE GROND EN DE OPSTAND DAARVAN.}

$a$. De grond is het eigendom van den Sultan van Ternate.

Natuurlijk wil dit zeggen: de grond is het eigendom van den "landsvorst". Men hoort ook dikwerf de uitdrukking: de grond is van de "Compagnie". Men heeft de vaste meening, dat de 7• Volgr. IX. 
grond als zoodanig niet het eigendom is der gemeenschap, maar van den Vorst - niet als Hoofd der gemeenschap beschouwd, want niemand denkt zich den Sultan van Ternate of het Hollandsch Gouvernement als Hoofd der gemeenschap - maar als buiten of boven die gemeenschap staande Heerscher, op wiens grond men woont.

b. De eerstontginuer van den grond krijgt daarop het gebruiksrecht zoowel voor zich, als voor zijn erfgenamen. Dit recht verjaart niet, maar het kan wel verkocht worden.

Wie echter het gebruiksrecht van den grond koopt, koopt daarmede niet den opstand van boomen of gewassen, die daarop gevonden mochten worden, hij moet dien opstand koopen van dengene die ze geplant of onderhouden heeft, indien n.l. de eigenaar een ander is dan die van het gebruiksrecht van den grond.

Indien echter iemand een aanplant verkoopt, verkoopt hij daarmede ook het gebruiksrecht op den grond waarop zich die aanplant bevindt.

Dit gebruiksrecht grenst echter tamelijk dicht aan eigendomsrecht. Onder "ontginnen" verstaat men bepaaldelijk "ontbosschen". Natuurlijk, oorspronkelijk was alles bosch! Wel zijn er nu heele alang-alang-velden maar, met uitzondering van sommige stukken, door boschbrand ontstaan, hebben die ook alle eigenaars. Daar echter het ontginnen soms reeds vijftig, misschien reeds honderd jaar geleden is, kost het wel eens moeite, den rechtmatigen eigenaar op te sporen, angezien onder de Alfoeren zelve, het recht op alang-alang-velden niet bijzonder gehaudhaafd wordt, te meer niet, daar de ontgonnen velden niet verdeeld worden, maar eenvoudig bij den dood van den eigenaar aan de familie verblijven. Al de erfgenamen maken er gebruik van, zoo het hen gelust. Wil echter een buiten de familie staand persoon er gebruik van maken, voor één keer om er op te tuinen, of om voor goed te naasten, dan moet hij betalen, òf huur, per tuin en per rijstoogst een gulden, òf den koopprijs, per tuin een rijksdaalder. De grootte van een tuin is verschillend, maar is toch zelden meer dau $\frac{1}{2}$ H.A. Neemt men nu een stuk grond in gebruik, dan doet eenvoudig de familie zich gelden, tenminste een der leden ervan, die dan beweert er recht op te hebben. Gebeurt het dan, dat men betaalt aan de niet-rechthebbenden, dan geeft dit wel aanleiding tot processen onder de familieleden onderling, maar het eigendomsrecht van den kooper blijft onaangetast.

De aanplant hoort echter niet in den koop. Deze is geheel van den grond te onderscheiden. Bijvoorbeeld: $A$ heeft van $B$ een stuk grond gehuurd voor één jaar, of voor langer, om er 
op te wonen. Hij plant daarop vruchtboomen en verlaat daarna den grond weder. De grond keert nu terug aan den eigenaar, maar de boomen blijven het eigendom van den planter. Of wel, iemand plant een boom op grond, die hem in het geheel niet behoort, dien hij ook niet gehuurd heeft. Toch wordt de aldus geplante boom zijn eigendom.

Ik kocht, bij mijn komst te Tobèlo een erf, ontgonnen grond, de anplant was echter niet in den koop begrepen. De grond had één eigenaar, de aanplant vele. Ik heb het tieu jaar İang moeten aanzieu, dat op mijn eigen erf de vruchten geplukt werden door deze en gene, tot tijd en wijle de eigeuaars der boomen eeus gebrek aan geld kregen, en dus geuegen waren de boomen te verkoopen. Na tien jaren waren ze nog niet alle in mijn bezit geraakt. Eén manggaboom, met heerlijke vruchten, had ik reeds lang willen koopen, maar de verkooper van den grond die er geregeld de vruchten van plukte, weigerde. Hij had het geld niet noodig, en had liever de vruchten. Tot ik op zekeren dag ontdekte, dat die boom niet door hem geplant was, maar door een oude vrouw, die hier eens een tuintje gemakt had, en den boom reeds lang geleden had verkocht aan een handelaar. Toen had ik hem natuurlijk spoedig in eigendom.

Op hetzelfde erf stond een pol sagopalın. De grensscheiding werd gevormd door een riviertje, en die sagopol stond juist op het erf, ann den kant van 't riviertje. Ik kon den eigenaar niet beletten naar zijn eigendom te gaan en had dus ook geen vrijheid van afsluiting van het erf. De eigenaar weigerde beslist de sago te verkoopen, en ik was genoodzaakt de bedding van 't riviertje te verleggen, achter de sagopol om.

Ik ontgon een stuk grond voor den aanleg van een kelapatuin. Die grond scheen niets dan oerwoud te dragen, maar spoedig kwam iemand opdagen, die beweerde, dat zijn overgrootvader daar door een slaaf een tuin had laten maken. De aanspraken waren echter ditmaal nog al zwak, omdat de grond weer met volkomen zwaar bosch begroeid was, zoodat "de moeite voor mijn bijl niet minder was dan voor die van den eerstontginner. Toch heb ik moeten betalen, niet alleen voor dien grond, maar ook voor vruchtboomen, die men daar vroeger geplant zou hebben, en die wel niets opleverden, maar toch iets opgeleverd zouden hebben, indien de eigenaars ze maar schoongemakt hadden.

Koopt men echter een bepaalden aauplant, een kelapa-aanplant, een sago-aauplant, dan koopt men aauplant en grond beide, tenzij natuurlijk het tegenovergestelde uitdrukkelijk bedongen wordt.

c. In het district Galé'a heeft elk stamdorp zijn begrensd gebied in het bosch. Elk der leden van het stamdorp mag uit dit gebied halen wat hij weuscht. Lieden van andere dorpen, mogen uit 
dit gebied niets halen, zonder voorafgaand verlof van het Hoofd van het betrokken stamdorp.

In de districten Tobèlo en Kau kent men geen bepaalde grenzen der stamdorpen. Het bosch is daar algemeen eigendom, waaruit elk eenvoudig neemt wat hem goeddunkt.

Ik weet niet, of dergelijk recht ook bij andere stammen heerscht, maar ik geloof het niet. Hoe de Galélarcezen er toe komen, begrijp ik ook nog niet. Klaarblijkelijk is bij hen het algemeen stamverband niet zoo sterk meer, als bij hun vorige landgenooten. Ook heeft wellicht de wijze van wonen, om het meer van Galéla, in tamelijk ver van elkaar verwijderde dorpen, er toe bijgedragen. De Tobèloreezen daarentegen woonden bij elkaar, wel in stamdorpen verdeeld, maar in elkaars onmiddellijke nabijheid. Ook was hun land wellicht betrekkelijk grooter, dan dat der Galélareezen. Zij woonden dicht bij elkaar en hebben zich van die hoofdvestiging uit, over het geheele district verspreid, elk nemende wat hem goed dacht, door elkaar, naar elks lust.

d. Boomen in het bosch zijn het eigendom diergenen, die ze van een eigendomsteeken voorzien. Aldus zijn ook de gom-copalboomen het eigendom van hem, die ze voor de eerste maal aantapt of inkeept.

Dit geldt van "boschboomen", door niemand geplant natuurlijk. Bv., iemand wil een huis bouwen en gaat nu naar het bosch, zoekt de boomen uit, die hem voor dit doel dienstig zijn, en geeft daar een hak in. Deze zijn daardoor de zijne geworden, en een fatsoenlijk man zal zich nooit boomen toeëigenen die door een ander aldús gemerkt zijn. Ook lieden die prauwen maken, merken wel lang van te voren, voor hun doel geschikte boomen. Sommigen echter beweren, dat een hak of keep niet genoeg is, en dat, om het eigendomsrecht te handhaven, de plek rond de boom ook schoongemankt en schoongehouden moet worden. Dergelijk schoonmaken gebeurt ook wel door lieden, die zich het recht op een vruchtboom wilden toeëigenen, die eigenlijk familieëigendom is. Voor één pluk wordt dan dat recht erkend.

Eenmaal besteedde ik het leveren van ijzerhout aan. Drie lieden, nog al brutaaltjes, gingen toen naar een zeker eiland dicht in de buurt, en voorzagen al de goede ijzerhoutboomen van een eigendomsteeken, niet, omdat het district niet genoegzaam boomen had, maar omdat ze op dat eiland dicht aan zee stonden, en dus gemakkelijk te vervoeren waren. Anderen, die ook dadelijk een begeerig oog op die boomen sloegen, wilden het aldus genomen recht niet erkennen. Het werd een rechtzaak, en toen werd uitgemaakt, dat in dit 
geval, de drie menschen onrecht hadden. Het ijzerhout was voor allen, allen hadden het noodig, dus was het zich toeeigenen door die drie, onder deze omstandigheden, als roof te beschouwen.

Is het in het algemeen bewezen, dat iemand een gemerkten boom genomen heeft, vooral als daaromheen ook nog schoongemaakt is, dan wordt dit feit als diefstal vervolgd.

De meeste zaken echter ontstaan over de gom-copalboomen. In het district Tobèlo komen die niet voor, wel op het (half Tobèloreesche, half Galélareesche) eiland Morotai. Het komt n.l. heel veel voor, dat niet de boomen natuurlijk, maar de gom gestolen wordt, die uit de gemakte inkervingen gevloeid is. Natuurlijk zijn dergelijke diefstallen voor den inlandschen rechter moeilijk te bewijzen.

De gom-copalboomen zijn een kostbare bezitting, ze gaan ook gewoon als eigendom, met de erfgoederen over, en blijven dan behooren tot het familiebezit. Ook onder de familiën ontstaat dan nog wel eens twist naar anleiding dier boomen, maar toch niet zoo heel veel. Men gat mar eens nu en dan die boomen opzoeken als men geld noodig heeft, en gewoonlijk doen verschillende familieleden dit niet terzelfder tijd, zoodat men elkaar wel uit den weg loopt.

$\mathrm{Op}$ het eiland Morotai kwam het een paar jaren geleden voor, dat slimme handelaren, Chineezen, maar ook veel Arabieren van de bevolking de gomboomen gekocht hadden, d.w.z. ze beweerden dat zij ze gekocht hadden. Eigenlijk hadden ze de bevolking eerst in schuld gebracht, en toen voor de schuld de boomen maar genomen. Hierover ontstond groote ontevredenheid. Men scheen te meeneu, of te gevoelen, dat toch de boomen geen eigendom waren, en dat het recht tot aftappen der gom niet a an vreemden verkocht kon worden. De boomen, het bosch is het eigendom der opwonende inlandsche bevolking. De bevolking erkent het bezitrecht van den Sultan van Ternate, maar meent dat zij, door belasting te betalen, recht krijgt op de opbrengst van zee en land, voor zoover dit geen particulier eigendom is geworden. Een vreemde echter deelt dat recht niet, en men voelde zich dus zeer bezwaard, door het in eigendom overgaan der gomboomen aan de handelaren. De Sultan van Ternate hoorde van de zaak en zond een vertegenwoordiger, om namens hem recht te doen. Het recht der inlandsche bevolking op de bosschen werd erkend, de handelaren moesten er afstand van doen, maar ieder der bevolking die klachten iubracht, moest, om zijn rechten erkend te zien, een aanzienlijke som aan des Sultans vertegenwoordiger betalen; wilde of kon men dit niet, dan erkende de Sultan het eigendomsrecht niet, en op deze wijze werd een belangrijke som in de kas van den Sultan van Ternate gesleept, of door diens Hoofden gestolen, 't geen voor de bevolking toch op hetzelfde neerkwam. 


\section{B. Over Dorpsrechten.}

$a$. Ieder is verplicht in een dorp te wonen.

Deze bepaling is geenszins overbodig. Vroeger toch bestond zij niet. Wel was iedereen lid van een der vier stamdorpen, maar die stamdorpen hadden niets locaals. Dus was men ook niet onderworpen geweest aan plaatselijke Hoofden, wel aan stamhoofden. De nieuwe toestand bracht echter het wonen in dorpen mede. Het Christendom verwekt van zelf locale belangen, en bevordert daardoor dorpstichting. De kinderen moeten school gaan, de kerk moet bezocht worden. School en kerk zijn het eigendom der bevolking en worden dus niet een stambelang, maar een plaatselijk belang. Van zelf moest men nu komen tot locale Hoofden. Een aantal menschen, die dezelfde belangen hebben, moeten een gemeenschap vormen, en die gemeenschap vereischt een Hoofd, zoo ze zal blijven bestaan. Het district werd dus verdeeld in dorpsgebieden, en nu is het van het hoogste belang, dat de geheele bevolking zich in de angelegde dorpen vestigt. Over het geheel was dit reeds het geval, maar er waren (en zijn) nog altijd enkelen, die, om aan de dorpsdiensten te ontkomen, in de bosschen blijven zwerven, zonder vaste woonplats. Het heet dan dat men in die bosschen tuinen maakt, en tuinen maken is natuurlijk aan elk toegestaan, zoo slechts in een der dorpen een huis gebouwd is, dat als vaste woonplaats geldt. Op de verplichting tot het hebben van zulk een huis, ziet de bepaling.

b. Wie verhuist naar een ander dorp, zonder daarvan kennis te geven aan het Hoofd van het dorp, waarin zijn vorige woonplaats was, zal f $5 .-$ boete betalen.

Deze bepaling is zeker heel goed gemeend, maar alleen een heel krachtig dorpshoofd weet zich aldus te doen gelden.

c. Wie door zijn dorpshoofd gelast wordt, den weg in het dorp schoon te maken, en niet aan dit bevel voldoet, verbeurt cene boete van f 0.50 tot $\mathrm{f} 3$. - , naar overweging der rechters.

Hieromtrent geldt hetzelfde, als wat gezegd is omtrent " $b$ ". Sommige dorpen zien er goed uit, anderen zijn vol onkruid. Het eene Hoofd heeft maar te spreken, en de weg wordt gewied, anderen weten het zelfs met dreigementen zoover niet te brengen. De toestand zal wel beter worden, maar langzamerhand, naarmate het gezag doorwerkt. De meeste moeite ontstaat, doordien verschillende Hoofden zich tegenover hun familie, vooral tegenover hun schoonfamilie, niet genoeg weten te doen gelden. Bij een eerste bevel gehoorzamen de goedwilligen. Worden de kwaadwilligen ook tot hun plicht gebracht, dan blijven de goedwilligen gewillig; gebeurt dit niet, dan is bij een tweede bevel ieder kwaadwillig. 


\section{HOOFDSTUK II.}

\section{HET ERFRECH'T.}

$a$. Wanueer iemands vrouw sterft, erft de man 't geen door de echtgenooten tijdeus het huwelijk verkregen is. Ook erft hij 't geen van de vrouws-familie mocht ontvangen zijn, als tegengeschenk voor den bruidsschat (ma kimànga). Datgene echter, wat de vrouw in bezit of gebruik had, uit de erfgoederen harer familie, gaat naar haar familie terug.

Men kan dus kortweg zeggen: de man is erfgenaam zijner vrouw. Natuurlijk is hierbij verondersteld, dat de bruidsschat betaald is. Is die niet betaald, dan is van een eigenlijk huwelijk geen sprake; het is niet meer geweest, dan een samenleven; de vrouw is niet door den bruidsschat van haar eigen familie gescheiden, en het eigendom der mans-familie geworden, en wat zij nalaat tot zelfs haar kinderen toe, is niet het eigendom van haar man, maar van haar eigen familie.

De laatste bepaling ziet op goederen, die een vrouw, dikwijls uit haar eigen familiegoederen nog in gebruik heeft, feestkleederen, vaatwerk en dergelijke, ook zelfs wel tuingronden, maar is haar bruidsschat betaald, dan heeft zij die goederen niet meer dan in leen, dus spreekt het van zelf, dat zij tot hare familie terugkeeren.

b. Indien een gehuwd man sterft, zonder kinderen na te laten, wordt, hetgeen tijdens het huwelijk verkregen is, geërfd door zijne weduwe.

Indien de weduwe weer een huwelijk aangaat, wordt de erfenis gelijkelijk verdeeld tusschen de broeders van haar overleden man en haar.

Familiegoederen welke de man in gebruik had, keeren terug tot zijn familie, familiegoederen welke de vrouw in gebruik had, keeren terug tot haar familie.

De vrouw erft van haar man dus niet zoo onbepaald, als de man dit van zijn vrouw doet. Dit zit natuurlijk in het huwelijksrecht. De vrouw is door het betalen van den bruidsschat, een lid, liever nog eigendom geworden der mans-familie, en de goederen van den man blijven dus familie-eigendom, ook zoo ze in haar hand blijven. Gaat zij echter opuieuw een huwelijk aan, dan gaat zij in eene andere familie over, en de familie van haar eersten man eischt nu hetgeen zij geërfd heeft op, omdat zij dit natuurlijk slechts als lid der familie bezeten heeft. 
De deeling geldt alleen hetgcen door beiden tijdens het huwelijk verworven is, en niet de familiegoederen. Daarop heeft ze geeu recht, haar man had ze ook slechts geleend. Wat tijdens het huwelijk verworven is, wordt voor de helft als het hare beschouwd en die helft mag zij dus behouden.

c. 1. Wanneer een man sterft, nalatende onmondige kinderen, komt zijn erfenis aan zijn vrouw. Zij mag daaruit haar eigen onderhoud en dat harer kiuderen bestrijden. De broeders van den gestorven man moeten er voor waken, dat de erfgoederen uiet verloren gaan.

2. Indien, tijdens het overlijden des mans ziju kinderen reeds mondig zijn, wordt hetgeen tijdens het huwelijk verkregen is, gedeeld tusschen de moeder en de kinderen, waarbij aan de kinderen $\frac{2}{3}$ deel, en aan de moeder $\frac{1}{3}$ deel komt.

3. Indien de weduwe sterft of huwt, komen haar kinderen en haar erfenis, onder voogdijschap van de broeders haars overleden echtgenoots.

De laatste zin van alinea 1 schijnt in strijd te zijn met het voorgaaude. Toch is dit niet zoo. Is baar geld aanwezig, dan mag dit natuurlijk door de vrouw gebruikt worden en verbruikt, zonder dat men haar rekeuschap zal vragen, zoo zij n.l. ongehuwd blijft. Huwt zij spoedig weer, dan worden ook wel eens nog annwezige gelden vau haar geeischt. Verder zijn er tuinen, tuinopbrengsten etc. Dat heeft natuurlijk geen blijvende waarde, evenmin gewone kleederen. Zijn er echter aanplantingen, dan beschikt zij over de vrucht daarvan, maar haar wordt niet toegestaan deze te verkoopen, ook niet, al heeft haar man die tijdens het huwelijk geplant. Desgelijks met metalen bekkens (gongs), waardevol aardewerk, pronkkleederen, sieraden etc. Zij mag dit alles vrijelijk gebruiken, maar verkoopen niet.

Onder alinea 2 wordt niet bedoeld dat alle kinderen groot zouden zijn. Is slechts de oudste zoon eenigszins volwassen, dan treedt die op als voogd over zijn jongere broeders en zijn zusters, en de deeling heeft dus plaats, kan plaats hebben tenminste.

Alinea 3 veronderstelt natuurlijk dat de kinderen nog klein zijn, want is de oudste zoon mondig, dan treedt die geheel in zijns vaders plaats.

Dat "huwen" voor een weduwe met "sterven" gelijk genoemd wordt, is recht, want door een huwelijk aan te gaan sterft zij der familie af.

d. 1. Alleen mannelijke kinderen zijn erfgenamen.

2. Indien de dochters tezamen met de zonen hun vader verplegen, en voor zijn begrafenis zorgen, kunnen zij ook een deel krijgen 
in de erfenis; in dat geval krijgen de zonen $\frac{2}{3}$ en de dochters $\frac{1}{3}$ der erfenis.

3. Dochters hebben mede het vruchtgebruik van de erfgoederen van hun familie, tot zij getrouwd ziju, huu bruidschat betaald, en de vergelding daarvoor gegeven is.

De bepaling onder al. 1 is natuurlijk noodzakelijk, niet zoozecr uit eeu minder-schatting der dochters, als wel, omdat die door een huwelijk het erfgoed uit de familie zouden kunnen brengen, waar streng tegen gewaakt wordt.

Al. 2 is dan ook reeds veel milder. Men zou zeggen dat het van zelf spreekt, dat de dochters hun vader verplegen, maar dat is toch zoo niet. Vooral als zij getrouwd zijn, trekken zij zich niets meer van haar ouders aan. Wel komt men bij elkaar voor de begrafenis, maar de bepaling ziet hoofdzakelijk op het verplegen en onderhouden tijdens ouderdom en ziekte. Het is daar gewoonlijk treurig mee gesteld. Is uitzicht op een (voor hier) rijke erfenis dan gaat het, maar is dit niet het geval, dan is het heel treurig. Ik zag eenmaal een oud man omzwerven, hasst dood van honger. Zijn zoon wilde hem niet verplegen, omdat de oude man, gebrek lijdende, eenige klapperboomen verkocht had, welke de liefhebbende zoon reeds als zijn rechtmatig eigendom beschouwde. Anderen wilden nu den ouden man wel in huis nemen, mits zij erfgenaam werden van de familiegoederen. Daar dit echter moeilijk te waarborgen was, vond hij nergens een onderkomen.

Het is verder duidelijk, dat de verdeeling alleen ziet op de roerende goederen en niet op de familiegoederen, dus, op wat tijdeus het huwelijk verkregen was.

Volgens al. 3 hebben dochters recht op het vruchtgebruik der erfgoederen, zoolang ze niet, door het tegengeschenk der bruidschat van de familie afgestorven zijn. $\mathrm{Nu}$ wordt echter, Hoofdstuk IV letter $k$ bepaald, dat dit tegengeschenk onder christenen niet meer gegeven wordt, aangezien de bruidschat daartoe te laag is, en de vrouwen toch, na hun huwelijk, het recht niet behouden op de erfgoederen, waardoor dus de laatste zin van deze alinea overbodig wordt.

Hier is niet uitgedrukt hoe het staat met het erfrecht van onwettige kinderen van zulke vrouwen, die als erfgenaam hunner moeder recht zouden hebben ook in haar plaats recht op zulke erfgoederen te doen gelden. De kwestie is niet gesteld, maar ik denk, dat mogelijke onechte kinderen, die zij mocht verkrijgen, in haar rechten treden, maar echte kinderen niet, angezien die door hun geboorte eene andere familie toebehooren. De moeder blijft toch, zoolang haar bruidschat niet vergolden is, feitelijk tot haar eigen familie behooren.

$c$. Indien alleen dochters nablijven, zijn deze erfgenamen. 
Indien zij getrouwd zijn, haar bruidsschat betaald en reeds vergolden is, hebben zij echter geen recht meer op de goederen van haar eigen geslacht.

De dochters zijn dus alleen erfgenaam van de roerende goederen, niet vau de familiegoederen. Daarvan krijgen zij alleen behcer, en genieten het vruchtgebruik ervan. Door huwelijk en tegengeschenk van den bruidsschat verliezen zij ook het laatste. Het erfgoed keert dan eenvoudig naar de familie des vaders terug, volgens de bepaling van art. 9. Zijn zij reeds getrouwd, en is de bruidsschat reeds vergolden tijdens het sterven, dan is er natuurlijk niet eens sprake van rccht krijgen op de familiegoederen. De familie des vaders treedt dan dadelijk in alle rechten.

$f$. 1. Indien beide ouders sterven, terwijl de kinderen allen onmondig zijn, komt hun erfenis onder beheer vau de broeders van hun vader.

2. Is de oudste zoon reeds mondig, dan krijgt hij het behecr over zijn broeders en zusters, en over het erfgoed.

3. Bij mondig worden der kinderen kan het erfgoed verdeeld worden, het is echter niet noodzakelijk.

Het is natuurlijk de oudste broeder van den vader, die de voogdijschap op zich neemt. Zijn de nagelatenen alleen dochters, dan blijft hij over haar al de rechten van den vader uitoefenen, geeft ook ten huwelijk, ontvangt bruidsschatten etc. Had de vader geen broeders, dan komt, zoo deze leeft, de grootvader, d. w. z. de vader des vaders, an de beurt, of zoo deze reeds overleden is, diens broeder of de kinderen van de broeders van den vader. Het blijft dus altijd in de mannelijke lijn.

Alinea 2 "mondig", moet men niet Europeesch verstaan. Er is geen leeftijdsgrens voor. Men zegt eenvoudig "hij is geen kind meer" en de persoon in kwestie is dan, naar onze begrippen dikwijls nog volkomen kind. Echter zijn hier aankomende jongens dikwerf zeer brutaal, en het ligt maar an meerdere of mindere brutaliteit van zoo'n jongen, of hij spoedig het gezag op zich neemt of niet.

Er is ook geen wettelijke handeling toe noodig, om de voogdijschap op hem te doen overgaan. Het gaat alles zoo van zelf. Dat echter, juist door die ongeregeldheid heel veel processen ontstaan, is geen wonder.

Een broeder echter vertreedt volkomen den vader, natuurlijk de oudste.

De verdeeling al. 3 genoemd, heeft zelden plaats indien men geen twist krijgt.

g. Indien een ongehuwde man of vrouw sterft, zijn zijn (haar) ouders 
erfgenamen. Zijn deze niet meer in leven, dan zijn de broeders en zusters, of kinderen der broeders en zusters, erfgenamen.

Was hij (zij) eenigst kind, en zijn de ouders reeds overleden, dan zijn de broeders des vaders, of kinderen daarvan die hem (haar) verpleegd hebben, erfgenamen.

Hier komt meer op den voorgrond: het verpleegd hebben. Heel veel komt het niet voor, uit den aard der zaak 't meest nog met vrouwen. Van die is echter ook al heel weinig te erven, het gevolg is, dat ze in den regel ook al heel slecht verplecgd worden.

Het is feitelijk het ergste wat iemand gebcuren kan, alleen achter te blijven, of alleen te staan.

h. Stiefkinderen erven, tezamen met eigen kinderen, hetgeen door de ouders, tijdens het huwelijk verworven is, maar op de familiegoederen huus stiefvaders hebben zij geen recht.

De laatste bepaling is natuurlijk volkomen recht, angezien dergelijke kinderen immers een eigen vader gehad hebben, en dus ook in diens familie thuis behooren. Erfden zij ook van hun stiefvader, zij zouden twee erfporties hebben.

$i$. Indien de moeder van buiten echt geboren kinderen huwt, verkrijgen die kinderen het erfrecht op hetgeen door hun moeder en stiefvader tijdens het huwelijk verworven wordt, maar krijgen geen recht op de erfgoederen hunner ouders.

De laatste bepaling sluit zich aan bij 't bepaalde in de vorige paragraaf, alleen wordt dezen kinderen ook den weg tot het erfgoed hunner moeders gesloten. Feitelijk hebben die dat natuurlijk ook niet, wel het vruchtgebruik van het erfgoed van haar eigen familie, en ik meen wel, dat haar natuurlijke kinderen dit recht met haar deelen en erven. Zij zijn echter altijd in zeer slechte conditie, aangezien zij geen wettigen vader hebbeu, die hen in eene familie inlijft.

\section{HOOFDSTUK III.}

\section{Over PLEEGKINDEREN (ADOPTIE).}

a. 1. Men kan pleegkinderen aannemen uit de eigen familic en ook daarbuiten.

Het aannemen van pleegkinderen kan op tweeërlei wijze geschieden.

Ten eerste: $\mathrm{Bij}$ de geboorte, met volkomen overgaaf van het kind aan de pleegouders, en afstand door de natuurlijke ouders van alle rechten en plichten. 
Dit komt nug al eens voor in de districten Tobèlo en Kau dus bij den Tobèloreeschen stam. Het betreft dan kinderen die z. g. n. "weggegooid" worden, dat wil zeggen, kinderen dien de ouders niet willen grootbrengeu. Hiertoe kunnen verschillende redenen zijn bijv. dat men al kinderen genoeg heeft, dat men geen meisjes meer hebben wil, dat er booze voorspellingen over het kind zijn, dat er tweelingen zijn en men er slechts één wil grootbrengen; ook, dat verscheidene kindereu achter elkaar gestorven zijn, en men dus meent, door booze geesten van kinderen beroofd te worden. In het laatste geval kan het uit liefde voor het kind geschieden, om het door anderen in het leven te doen behouden. Beslist hiervan te onderscheiden is het, wanncer bv. kinderlooze echtelieden kinderen aaunemen reeds voor de geboorte ervan, ook wel na de geboorte, om op deze wijze kroost te verschaffen. Hoewel n.l. zulke kinderen ook ten volle aan de pleegouders overgaan, worden zij toch door de eigen ouders niet verloochend, zooals in het eerste geval, en zij blijven zelfs dikwijls in handen der moeder, die ze, tegen vergoeding, zoogt.

Ten tweede: Wanneer het kind reeds eenigen leeftijd bereikt heeft; het dan wordt aangenomen, omdat men er veel van houdt, maar men krijgt het niet ten volle in zijn macht daar het bij afwisseling vertoeft in het huis der ouders, en dat der pleegouders.

2. Indien een kiud als pleegkind aangenomen wordt, moet daarvan aan het kamponghoofd kennis gegeven worden.

3 . Het is weuschelijk dat meu, als teeken van aanneming van een kind tot pleegkind, de moeder een sarong of een slendang geeft.

Het is gewoonte bij de Galélareezen, om de moeder vijf realen (f 8.-) te geven, als loon voor het zoogen, en een baadje met een sarong. Wordt dat niet gegeven, dan hebben later de eigen ouders recht op de helft van den bruidsschat (natuurlijk indien het pleegkind een meisje is).

Volgens adat der Lodareezen, wordt de bruidsschat in elk geval gedeeld tusschen eigen ouders en pleegouders.

Adat der Tobèloreezen is als volgt: indien het kind aangenomen is volgens wijze I, krijgen de eigen ouders niets, noch voor de moeite van het zoogen, noch van den bruidsschat, maar is het aangenomen volgens wijze II, dan krijgen de eigen ouders de helft van den bruidsschat.

De bepaling onder alinea 2 is later gemaakt, omdat allerlei kwesties ontstaan over dit pleegkindschap. Het werd gewoonweg maar zoo eens gezegd: ik neem dit kind aan. Dan kwam het voor, 
dat de moeder, anngezien zij reeds een jonger kind had, wel van de zorg voor een ouder ontheven wilde zijn. Stierf dan echter het jougere, en de pleegouders wilden hun recht geldend maken op het oudere, dan werd het geweigerd.

Of wel, een kind was geadopteerd, maar men had zich over de heele adoptie nooit bekommerd, tot tijd en wijle het kind huwbaar was, als wanneer men zich plotseling herinnerde dat men als pleegouders recht had op de helft van den bruidsschat, etc.

Natuurlijk was dit een vruchtbare bodem voor processen, en om die te voorkomen, werd bepaald, dat adoptie moest geschieden ten overstaan van het kamponghoofd, 't liefst met het geven van een geschenk, als onderpand van de verbintenis.

Dit sluit natuurlijk in, dat men geen proces kan beginuen over adopties, die niet geschied zijn ten overstaan van het kamponghoofd.

Het geven van iets, is bij de Tobèloreezen niet verplichtend, gelijk over het geheel bij hen het aannemen veel meer werkelijkheid is, dan bij de andere stammen. Bij die toch, kan nen het geven van het "zoogloon" en wat er bij behoort, een soort koopen vinden, van het recht op den lateren halven bruidsschat, zoodat feitelijk de rechten der eigen ouders geheel onverkort blijven.

b. 1. De eigen ouders mogen het pleegkind niet bevelen iets te doen, zonder voorkennis van de pleegouders.

2. Een pleegkind wordt volkomen gelijk gesteld met een kind, en erfgenaam van ziju pleegouders; het heeft echter geen erfrecht meer op zijn eigen ouders.

Een kind kan dus nooit van twee vaders erven, aangezien de adoptie hem wel erfgenaam makt van zijn pleegouders, maar hem uit de eigen familie sluit. $\mathrm{Nu}$ zou het natuurlijk kunuen, dat men, om eigen kinderen te benadcelen, reeds bejaarde pleegkinderen aannam, maar dat komt toch niet voor.

De adoptie bepaalt zich tot de jeugd, gewoonlijk zelfs tot de prille jeugd.

3. Is een pleegzoon ouder dan de eigen zonen, dan wordt hij ook hoofd van zijn pleegbroeders en -zusters, volkomen als een eigen zoon.

c. 1. Indien, volgens beslissing der rechters, pleegouders een pleegkind niet goed verzorgen, kan het door de eigen ouders teruggeëischt worden, zonder schadevergoeding te betalen aan de pleegouders.

Dit geldt niet voor die kinderen in de districten Tobèlo en Kau, die op de eerste wijze zijn aangenomen, aangezien de ouders 
die weggeworpen hebben, en dus er geen recht meer op kunnen doen gelden.

2. Indien een pleegkind uit ondeugd bij zijn pleegouders wegloopt, en zijn eigen ouders willen het terugnemen, dan moeten zij aan de pleegouders verpleegkosten betalen à f 0.07 per verpleegdag.

Bepaling alinea 1 is ook later gemaakt om misbruik tegen te gaan. De jeugd is nogal ongehoorzaam; tuchtiging aan de zijde der ouders heeft zelden plaats. Kreeg dus zulk een ondeugend pleegkind een pak slaag, dan liep het eenvoudig naar zijn eigen ouders terug, die het dan weer behielden, onder voorgeven, dat de pleegouders er niet goed voor zorgden.

Dit bleef dan op zijn beloop, tot na tijd en wijle een proces outstond, aangezien de pleegouders verplegingskosten eischten.

$N u$ moeten dus de Hoofden uitmaken of werkelijk de verpleging slecht is ('t geen ook wel voorkomt), een ieder mag niet zijn eigen rechter zijn. Willen de ouders uu toch hun kind de hand boven hēt hoofd houden, dan moeten zij, volgens al. 2 behoorlijk betalen.

De op de eerste wïze aangenomen kinderen bij de Tobèloreezen hebben natuurlijk geen andere ouders dan de pleegouders, die zijn volkomen eigen ouders geworden.

Er is in dit alles geen sprake van het belalen van den bruidsschat voor aangenomen zoons. Dit behoeft ook niet aangezien dat slechts eene zedelijke verplichting is. Eeu eigen vader behoeft dat niet te doen, dus ook een pleegvader niet, Regel is echter, dat bij aanneming op de eerste wijze de pleegvader hiervoor geheel opkomt, of anders diens familie. In het tweede geval helpt ook de eigen familie mee.

\section{HOOFDSTUK IV.}

\section{Over het huwelijk.}

\section{A. Verboden graden om te huWen.}

$a$. Zij die in één huis wonen en verpleegd worden, mogen niet met elkaar trouwen, n.l.

1. eigen broeders en zusters.

2. stief broeders en -zusters.

3. pleegbroeders en -zusters.

4. pleegvader of stiefvader met pleegdochter of stiefdochter.

5. pleegmoeder of stiefmoeder met pleegzoon of stiefzoon.

Men ziet, dat onder 2 en 3 twee graden opgenoemd worden, die voor ons geen huwlijksverbod zouden insluiten.

Adoptie noch aanhuwen doet een band des bloeds ontstaan, 
en zulk een huwelijk kan dus, uit ons oogpunt beschouwd, niet als bloedschending aangemerkt worden. Toch is het voor het gevoel der lieden hier beslist bloedschending. We zagen het, dat adoptie een band doet ontstaan, gelijk een die des bloeds, en dat wordt in deze bepalingen ook uitgedrukt.

Dat pleegouders of stiefouders zich vergeten voor hun pleegof stief kinderen, komt wel eens voor. Men denke aan de kleine Alfoersche woningen, den intiemen omgang der huisgenooten met elkaar, de ongekleedheid, de hartstocht van de Alfoeren.

Het komt zelfs voor, dat manneu hun vrouw verstooten, om met haar dochter (hun stiefdochter dus) te gaan leven.

Over deze handelingen spreekt ook de Heidensche maatschappij het veto uit, al zijn ze ook niet rechtstreeks strafbaar. Het veroordeelend gevoelen heeft in de Christelijke adat geleid tot deze verbodsbepalingen. Die zijn dus niet icts nieuws, maar drukken eenvoudig uit, wat elk gevoelt en denkt omtrent deze zaken.

b. Broeders- of zusterskinderen mogen niet met elkaar huwen.

Dit verbod kan opgeheven worden tegen eene betaling van f 10. - an den vader der bruid, boven den bruidsschat, voor "verbreking van de bloedverwantschap" (o ahali ma doaka).

Huwelijken in de verdere graden zijn natuurlijk geoorloofd, maar eene som tot verbreking der verwantschap, wordt geeischt bij de verste, soms zelfs zeer gezochte verwantschap, hoewel niet zoo veel als de bovengenoemde som.

Uit de bepaling blijkt, dat men oorsproukelijk niet in de familie gehuwd is, want het betalen van die som, is natuurlijk een pogen om de beleedigde adat te verzoenen, waruit volgt dat de adat is: alleen huwen buiten de verwantschap. Waarom men van dien regel afgeweken is, is niet na te gaan. Heel veel komt het trouwens ook niet voor dat neef en nicht met elkaar in het huwelijk treden, Laat men de adat onverzoend, dan is een kinderloos huwlijk hier het gevolg van. Het is natuurlijk mogelijk, dat men hiertoe gekomen is, doordien men zag, dat dergelijke huwelijken dikwerf onvruchtbaar waren, en dus daarom gemeend heeft, dat zij tegen de adat moesten ziju, en dus in de betaling een middel gezocht heeft, om de onvruchtbaarheid op te heffen.

Wanueer men $n u$ vraagt aan een Tobèlorees: vindt ge het huwelijk tusschen neef en nicht geoorloofd; is het antwoord: de een vindt het vies, de ander niet; die het niet vies vindt kan het wel doen.

Men gevoelt er dus het verkeerde niet van, maar laat het an ieders gevoel over, hoe in deze te handelen.

c. Christenen mogen alleen met Christenen huwen. 
Deze bepaling moest natuurlijk wel gemaakt worden. Laat ik er bijvoegen, dat het hoogst moeilijk valt, die te handhaven.

Slant een Christen jongeling het oog op een Heidensch meisje, dan wordt natuurlijk alles gedaan, om het meisje voor het Christendom te wiunen, maar zoo zij weigerachtig blijft, is de liefde voor de vrouw wel eens sterker dan de gehechtheid aan het Christendom. De Mohamedamen hebben in zulk een geval gemakkelijk spel. Zij laten het huwelijk stil begaan, maar na het huwelijk wordt de vrouw wel zoo bang gemankt voor dreigende onheilen dat zij gewillig het eten van varkensvleesch nalaat. Iets dergelijks zou het Christendom ook kunnen doen, ware het niet, dat dergelijke onware knoeierijen zijner onwaardig zijn.

\section{B. Over het SLUt'en van het HUWELIJK.}

$a$. Indien iemand wenscht in het huwelijk te treden, moet hij zijn voornemen bekend maken aan zijn kamponghoofd en aan den inlandschen helper zijner gemeente.

$b$. Het kamponghoofd moet onderzoeken of het huwelijk geoorloofd is volgens de vorenstaande bepalingen, wat afgesproken en beloofd is omtrent de huwelijksvoorwaarden tusschen de wederzijdsche familie van hen die in het huweilik wenschen te tredeu, en verder, of de man die in het huwelijk treden wil, een behoorlijk huis heeft in de kampong. Is de aaustaande man eenige zoon of de aanstaande vrouw eenige dochter, of wel, is een van beiden het eenige, nog bij zijn ouders, in huis zijnd kind, zoo kan toegestaan worden, dat het jonge paar bij de ouders gaat inwonen.

Dit, en ook andere bepalingen, die van de gewoonte afwijken, zal de Zendeling op den trouwbrief vermelden.

Het spreekt vanzelf dat deze bepalingeu, als ook de volgende, geheel nieuw zijn. Het heidendom kent geen vorm van huwelijken en in elk geval is het huwelijk daar iets, waar de Overheid ॥niets mee te maken heeft. De bepaling dat het kamponghoofd moet weten wat tusschen partijen bepaald is was noodig, omdat zoo'n huwelijk een ontzettend gesjacher tusschen de wederzijdsche families is, en er altijd heel veel twist ontstaat omtrent de verplichtingen, die men op zich genomen heeft, of heet op zich genomen te hebben. Daarom is bepaald dat huwelijksonderhandelingen gevoerd moeten worden ten overstaan van het kamponghoofd, opdat die wete wat bepaald en beloofd is, en natuurlijk, opdat, op wat nog geëischt mocht worden boven hetgeen aldus wettig bepaald is, geen verhaal te krijgen zij. 
De bepaling dat de man een huis moet hebben in het dorp is ook wel noodig bij een volk, dat eerstens neiging heeft, elke hut in het bosch als een genoegzame woning te beschouwen, en tweedens, met gansche familie bij elkaar woont in één huis. Dit laatste is natuurlijk niet geschikt om het huwelijksleven te bevorderen, maar het bevordert wel de onzedelijkheid. Men denke toch aan de soort van huizen, waarin elk kind alles hooren kan, wellicht nog zien ook; wat tusschen jonggehuwden voorvalt.

Daar het nu echter oude lieden heel moeielijk vallen kan, een huis te onderhouden, en het ook al niet te verwachten is, dat kinderen een huis zullen onderhouden, waarin zij niet wonen, is bepaald, dat één gezin bij de ouders mag inwonen, 't zij één schoonzoon, of wel één zoon.

Om moeielijkheden daarover te voorkomen, alsmede over allerlei andere bepalingen die gemaakt mochten worden, vond men goed dat dit alles op de huwelijksakte bijgeschreven werd. Ontstaat er nu moeite, dan begeeft men zich slechts tot den Zendeling, om zich te doen voorlezen wat bepaald is.

$c$. Wanneer het kamponghoofd dit alles onderzocht heeft en in orde heeft bevonden, brengt hij de lieden voor hun Zendeling. Nadat deze onderzocht heeft, of de bruidsschat reeds bij elkander gebracht en betaald is, siuit hij het burgerlijk huwelijk.

Eigenlijk mag geen huwelijk gesloten worden, zoo de bruidsschat nog niet betaald is, omdat het niet betalen van den bruidsschat, ook ontbinding van het huwelijk ten gevolge hebben kan. De bruidsschat is toch eigenlijk de eenige band, die de lieden birdt, bij het Heidendom natuurlijk, maar men kan niet verwachten, dat ook door de Christenen het bindende van het burgerlijk huwelijk of kerkelijk huwelijk, dadelijk gevoeld zal worden.

Wel worden er reeds huwelijken gesloten zonder bruidsschat, maar dat is toch een kleine minderheid. Meer worden er gesloten met allerlei bepalingen omtrent toekomstige betalingen, en deze moeten dan op de akte vermeld worden, en tevens moet den lieden goed aan het verstand worden gebracht, dat niet naleving dezer voorwaarden wel eeu proces, maar geen huwelijksontbinding ten gevolge kan hebben.

$d$. Hierna zal het huwelijk kerkelijk ingezegend worden.

Indien om een of andere reden de kerkelijke inzegening niet dadelijk op het burgerlijk huwelijk volgen kan, zullen de lieden zich echter, na het voltrekken van het burgerlijk huwelijk, als gehuwden mogen beschouwen.

Deze laatste bepaling ontstond, doordien het burgerlijk huwelijk gesloten werd ten kantore van den Zendeling, en $7^{\circ}$ Volgr. IX 
op diens woonplaats dus, en goedgevonden werd, het kerkelijk inzegenen in 't midden der gemeente in het dorp, waar de jonggehuwden woonachtig waren, te doen plaats hebben. Natuurlijk had de Zendeling dikwerf geen tijd, om dadelijk maar al deze gemeenten rond te reizen, alleen om een huwelijk in te zegenen, ja, daarover verliepen soms weken. Het ging niet aan, de lieden daarop te doen wachten, en vandaar de bepaling.

Later echter werd bevonden, dat de toestand zoo ook niet goed was, dus bepaald, dat de kerkelijke inzegening onmiddellijk op den burgerlijken trouwdag zou volgen en voltrokken worden in de kerk ter woonplaats van den Zendeling. Dat is dan ook zoo gebleven. Echter moet de bepaling van kracht blijven, want er zijn altijd huwelijken die niet kerkelijk ingezegend kunnen worden, doordien één der beide partijen nog geen Christen is b. v. en den Heiligen Doop nog niet ontvangen heeft, of doordien het jonge paar kennelijk reeds oneerbaar met elkaar leefde voor de huwelijksvoltrekking. De kerkelijke inzegening volgt dan later, maar het burgerlijk huwelijk geldt in die gevallen als huwelijk.

\section{Over den bruidsschat.}

$a$. De bruidschat is verminderd en vastgesteld volgens verlangen, en naar overweging der ondergenoemde Hoofden en Oudsten, zooals volgt :

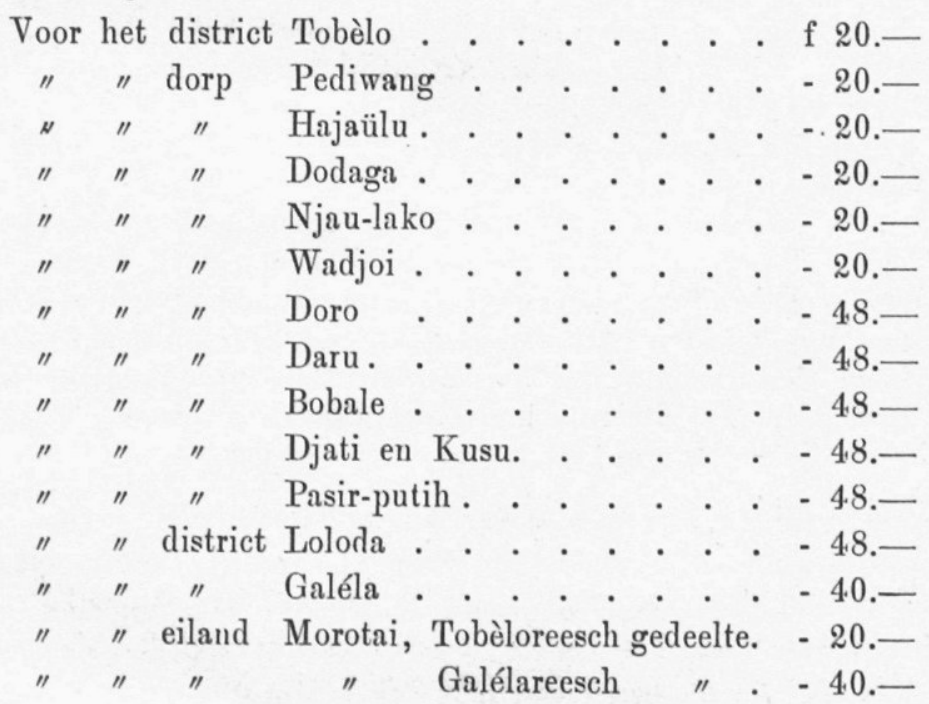

De bruidsschatten zijn natuurlijk veel hooger geweest, en het was juist dat hooge dat de Zending er toe bracht, te 
trachten ze geheel afgeschaft of verminderd te krijgen. Het eerste gaat niet, het laatste is gelukt, in theorie tenminste. In de practijk wordt nog menigmaal tegen een en ander gezondigd. Men betaalt gaarne veel, uit trotschheid of grootdoenerij. Echter is nu toch dit bereikt, dat niet meer het huwelijk ontbonden wordt om den bruidsschat. Men zorgt dat betaald wordt, wat door de nieuwe adat geëischt wordt en op het meerdere is, bij niet betaling, geen wettig verhaal, tenminste niet in zoover, dat het-wwelijk er door ontbonden zou worden. Hierdoor is dus ber gewenscht werd, n.l. iu de eerste plaats, het huwelijk not een vaste verbintenis te maken, onafhankelijk van den bruidsschat. Dat Tobèlo als district genoemd roert, en de andere streken dorpsgewijs is, omdat de Sangedji (het districtshoofd) van Tobèlo als zelf christen zijnde, deze bepalingen geldig kon verklaren voor al de dorpen in zijn district. In het district Geléla is slechts één christendorp, en evenzooveel waren er ook in het district Loloda, tijdens het opstellen van dezen adat, en die dorpen vertegen woordigden dus het Christendom in hun district. In het district Kau zijn wel veel christendorpen, maar niet onder een gemeenschappelijk Hoofd, dus kwamen al de dorpshoofden voor hun respectievelijke dorpen op.

Dat de dorpen Doro, Daru, Bobale, Djati, Kusu en Pasirputih een hooger bedrag stelden dan de rest, komt doordien in die dorpen de bruidsschat oorspronkelijk ook veel hooger was dan in de andere. Wellicht is die weelde ontstaan, doordien men rijk was geworden door het parelduiken, hetwelk in de zee waaraan die dorpen liggen, uitgeoefend wordt.

b. Wanneer een man huwen wil met een vrouw of meisje, wonende in een dorp waarin de bruidsschat lager is, dan in zijn eigen dorp, dan moet hij een bruidsschat betalen, zooals die in zijn eigen dorp is vastgesteld.

De billijkheid vorderde deze bepaling. Was zij er niet, dan zou men in de dorpen met hoogen bruidsschat heel voordeelig kunner handelen, door de zonen tegen lagen bruidsschat te doen huwen in de andere dorpen en de dochters tegen hooger bruidsschat uit te huwelijken.

$c$. Indien iemand wenscht boven den bruidsschat nog geschenken te geven aan ziju schoonouders, moet hij dat zelf weten, maar wanneer te eeniger tijd door procedeeren de bruidsschat terug betaald moet worden, zullen de rechters van zoodanige geschenken geen notitie nemen.

Dit is natuurlijk de eenige manier, om op den duur den hoogen bruidsschat te bekampen. Beletten kan men niet dat iemand zooveel geld aan een ander geeft, als hij wil. 
Wanneer echter alles, wat gegeven wordt bruidsschat is, komt het ook terug bij ontbinding van het huwelijk; krijgt echter het grootste gedeeIte het karakter van geschenk, zoodat men bij mogelijke scheiding, dat niet terug krijgt, dan moet dat op den duur het gevolg hebben, dat men dergelijke geschenken weigert te geven, want de bruidsschat is natuurlijk geen geschenk maar min of meer een "koopsom".

d. Omdat de bruidsschat nu veel minder bedraagt dan vroeger, geven de Christenen niet meer het tegengeschenk voor den bruidsschat ("ma sima" of "ma himanga").

De vrouwen zullen na haar huwelijk, geen recht meer hebben op het vruchtgebruik van de erfgoederen harer eigen familie.

Volgens oud gebruik wordt de bruidsschat an de schoonfamilie betaald, mar geldt als een soort standgeld, dat terug betaald moet worden, indien om redenen door de vrouw gegeven, het huwelijk ontbonden wordt.

$\mathrm{Nu}$ kan men de bruidsschat dit karakter doen verliezen, door het tegengeschenk te betalen, d. w. z. de familie die den bruidsschat ontvangeu heeft, geeft aan de familie des mans een tegengeschenk, welks grootte door de adat nauwkeurig bepaald is, eu dat wel zoowat tegen den bruidsschat opweegt.

Door het geven van dat geschenk wordt de bruidsschat z.g.n. gedood, dat wil zeggen die behoeft nu niet meer terugbetald te worden. Door dat tegengeschenk wordt de band, die de vrouw nog aan hare familie bond, verbroken. Is haar bruidsschat betaald, dan is zij daardoor nog niet geheel los van hare familie.

Die bruidsschat is als het ware het pand dat voor haar betaald wordt. Zij heeft daarvoor nog het recht, mee te genieten van de familiegoederen. Het tegengeschenk makt daar een eind aan. Dit tegengeschenk bestant echter nooit uit geld, maar uit rijst, goederen, matten, etc. De vrouwsfamilie brengt daarmede feitelijk het pand terug, makt zich daardoor geheel los van haar dochter, en laat ze nu over aan haar nieuwe familie. Volgt nu scheiding, of misdrangt zij zich, dan is die familie ook niet meer in het minst voor haar aansprakelijk.

Daar nu echter de christelijke adat slechts een kleinen bruidsschat kent en het tegengeschenk volgeus de gewoonte, meer is dan deze bruidsschat, vindt men goed het huwelijk als een volkomen losmaking te beschouwen, zoodat nu een christenvrouw door haar huwelijk volkomen aan haar mansfamilie komt te behooren.

Dit is ook meer in overeenstemming met den geest van het christelijk huwelijk. 


\section{OMTRENT SCHAKEN EN ROOVEN VAN VROUWEN.}

a. Wie eene vrouw des nachts, met haren wil schaakt, zal niet schuldig zijn, indien hij een teeken op de slaapplaats der vrouw achtergelaten heeft, en zoo spoedig mogelijk iemand zendt, om met de ouders der vrouw de huwelijksvoorwaarden te regelen.

Maar indien hij geen teeken achterlaat, en niemand zendt om met de ouders der vrouw te onderhandelen, zal hij gestraft worden met eene boete van f $1.60-\mathrm{f} 48$, naar bevind der rechters.

Het schaken te verbieden gaat niet. Het is ingeworteld. Het is natuurlijk ook de eenige weg voor twee gelieven, om den tegenstand eener onwillige familie te breken.

Het heeft echter zijn regels. Natuurlijk voorop gezet, dat het geschiedt na onderling goedvinden. Iemand, die tracht eeu schoone tegen haar wil te ontvoeren, valt onder het volgende artikel. Men gaat 's nachts met haar weg, maar de man legt b.v. zijn kapmes, zijn hoofddoek, of iets anders wat beslist voor hem kenmerkend is, op de slaapbank der schoone.

Ontwaken nu de ouders, en zien dat, dan kunnen zij volkomen gerustgesteld zijn omtrent de afwezigheid hunner dochter. Ze weten nu gewoonlijk al, met wien ze weg is, en kunnen de huwelijksonderhandelaars nu afwachten, die gewoonlijk ook al heel gauw komen.

Er moet uu evenwel een huwelijk tot stand komen, want de jonge dochter of vrouw is beschanmd gemakt, en de man evenzeer.

De onderhandeling mag in het begin wat stormachtig zijn, het komt wel in orde. De daad is dan ook niet strafbaar.

Is echter niet door iets achter te laten, kennis gegeven van wat gebeurd is, en verschijnen geen onderhandelaars, dan wordt bepaald een strafbare daad gepleegd, aangezien eerstens anleiding gegeven wordt dat de ouders uit boosheid of droefheid zich een ongeluk toebrengen, tweedens, alleenlijk weggeloopen wordt tot het plegen van overspel. Had men de bedoeling te huwen, dan kon men dit immers doen blijken.

b. Vrouwenroof is verboden. Wie zich daaraan schuldig maakt verbeurt f 48.- boete.

Er is ook hier sprake van iets, wat door de Heidensche adat toegestaan is.

Een meisje wordt, met of tegen haar wil, eenvoudig opgelicht en ergens in een huis opgesloten. Gelukt het haar te ontkomen, of gelukt het haar familie haar te bevrijden, dan is de zaak uit. Gelukt dit niet, en de gevangenschap heeft drie dagen geduurd, dan moet het meisje losgelaten worden. Weigert zij dan echter den man, voor wien zij geroofd is, te trouwen, 
dan moet zij een boete betalen, die nog al aanzienlijk is. Natuurlijk wordt, tijdens haar gevangenschap, getracht met haar familie te onderhandelen over de huwelijksvoorwaarden. Slagen deze onderhandelingen nu, dan looptalles op een bruiloft uit.

Maar onder de Tobèloreezen geeft het aanleiding tot bloedige tooneelen. De familie tracht dikwerf, heel kort aangebonden, met de wapens haar dochter te bevrijden, de partij, die haar gevangen heeft tracht dit te beletten, en men begrijpt wat het gevolg is. Om dit gevolg te voorkomen is het bij de Christenen verboden.

\section{E. Eenige zaken dIE bIJ HE'T HUWELIJK VERBoden ziJN.}

$a$. De gewoonte, dat een meisje, dat schoondochter wordt van een Hoofd, bij het eerste bezoek aan het huis harer schoonouders, dat huis kruipende moet naderen, terwijl twee leden van haar schoonfamilie zwaarden boven haar hoofd houden, is afgeschaft.

Dit was natuurlijk een heel vernederende gewoonte, in zwang bij de Kausche Tobèloreezen. Het is gewoonte, dat een nieuwe schoondochter eerst bij het Hoofd der familie gebracht wordt, om daar een dag, of eenige uren, tabak en pinang te presenteeren, als teeken dat zij als schoondochter de noodige onderworpenheid betoonen wil. Daar had men trouwens ook niets op tegen. Maar het kruipen tusschen twee mannen die elk een zwaard houden, zoodat de zwaarden boven haar hoofd een hoek vormen, vond men heel vernederend, en den nieuwen toestand onwaardig.

Gewoonlijk moest een tamelijk lange weg afgelegd worden. De schoonfamilie stond aan weerskanten geschaard, en al kruipende moest de nieuwe schoondochter hen de pinang en de sirih aanbieden.

๖. Indien iemand een meisje ten huwelijk vragt, mogen de ouders van het meisje geen geld meer van hem eischen tot schaamtedekking betreffende woorden, welke die man vroeger zou gesproken hebben, of handelingen, die hij vroeger zou verricht hebben, want had hij werkelijk iets verkeerds gedaan, dan moest daarover geklaagd zijn, ten tijde dat hij aldus handelde.

Hier is sprake van een gebruik om den bruidsschat nog wat te verhoogen. Gewoonlijk komt het bij de onderhandelingen aan het licht, dat het jonge mensch zich wel eens oneerbiedig tegen, of over een zijner a. s. schoonfamilieleden heeft uitgedrukt, of zich oneerbiedig tegen hen heeft gedragen. Men wil hem dan niet als schoonzoon aannemen, zonder dat die beschaamdheid eerst verzoend is door eene betaling. 
Natuurlijk betreft het altijd dingen, die geen wettelijke overtredingen zijn, maar slechts tot overtredingen uitgemeten worden.

Vandaar de bepaling dat zoo iemand werkelijk iets misdoet, dadelijk een klacht behoort te worden ingediend, onafhankelijk van het schoonzoonschap.

c. De gewoonte, dat alle leden van de familie der bruid, tijdens den engagementstijd voorwerpen of geld van den bruidegom ter leen vragen (met het doel 't gevraagde niet terug te geven) en zoo hij weigert te geven wat gevraagd wordt, hem dat op den trouwdag met een pak slaag te vergelden, tenzij dan, dat hij zich dat afkoopt, door elken afgewezen vrager $\mathrm{f} 2.50$ te betalen, is afgeschaft.

Deze gewooute is van den "Isam-stam". Het is natuurlijk ook een methode om het jonge mensch zooveel mogelijk geld af te halen. Daar nu echter bepaald was dat de bruidsschat niet meer dan de vastgestelde som zou bedrageu, schafte men deze gewoonte voor de Christenen af.

$d$. De gewoonte, dat elk van de leden der schoonfamilie het recht heeft op den trouwdag, of bij het bespreken der huwelijksvoorwaarden, een of ander voorwerp van den bruidegom te eischen ("o dungunu") wordt afgeschaft.

Ook al weer een methode om iets los te krijgen, wel niet voor de schoonouders zelf, maar toch voor de leden der schoonfamilie. Soms wordt het al bij het in orde komen der huwelijksvoorwaarden gezegd. Een der leden der schoonfamilie zegt dan eenvoudig: ik "dungunu" u voor een prauw, een kapmes, een mes, of iets dergelijks, en de bruidegom is dan verplicht het te geven. Hij zou in elk geval beschaand zijn om het niet te doen, al is het ook pas na jaren.

Volgens een andere gewoonte, geven op den huwelijksdag de jouge meisjes uit de schoonfamilie, de speelgenooten der bruid, allerlei voorwerpen aan den bruidegom, houtjes, pennetjes etc. onder bijvoeging: dit is mijn geweer, mijn kapmes, mes, koralensnoer etc. De bruidegom neemt dat aan, en moet nu teruggeven, alsof hij werkelijk die voorwerpen ontvangen had.

$e$. De gewoonte, dat de vrouw haar man aanklangt bij haar broeders, zoodat die broeders komen om hem een pak slaag te geven, indien niet de man zich dat met f 2.50 loskoopt, wordt a fgeschaft.

Indien een vrouw zich over haren man beklaagt bij haar broeders, moeten die de klacht brengen voor het kamponghoofd, opdat deze de anklacht onderzoeke. 
Dit was natuurlijk voor de vrouw een gemakkelijke manier, om zich op haren man te wreken, ofwel haar eigen familie te bevoordeelen. De zaken, waarover zij zich beklaagde, waren gewoonlijk van nul en geener waarde. Zij bleef echter op die manier steeds meesteres van den toestand, want bij het minste was het: ik zal het mijn broers zeggen.

$f$. Opdat niet meer de vrouwen de gewoonte zullen volgen, bij het minste woord harer schoonouders of van haar man, weg te loopen naar haar ouders of broeders, en niet terug te willen komen, voor zij een som gelds als "hartsmedicijn" (o hininga ma houru) heeft ontvangen, wordt bepaald dat, indien een vrouw wegloopt naar haar ouders of broeders, niet omdat haar man overspel bedrijft, maar om allerlei andere redenen, en haar familie ontvangt en herbergt haar, die f 3 boete zullen verbeuren, en indien haar man haar terug roept, en de familie houdt haar tegen, of herbergt haar nog langer, zoo zal die f 10 boete verbeuren.

Indien, naar het oordeel der vrouw, haar man of haar schoonfamilie tegen haar misdaan hebben, kan zij zich daarover beklagen bij het kamponghoofd, die de zaak zal onderzoeken. Maar eerst moet zij (zoo zij n.l. reeds weggeloopen is) tot haar man terug keeren.

Dit ziet op een heel onaangename gewoonte, die voornamelijk de Galèlareesche vrouwen eigen is. Bij het minste wat haar niet aanstaat loopen zij eenvoudig weg uaar haar eigen familie. Of zij nu gelijk heeft of niet, komt er niet op aan, haar familie geeft haar gelijk, en logeert haar. Zij gaat niet terug voor haar man haar komt halen, en stelt nu haar voorwaarden hoeveel zij hebben moet, om haar gewond gemoed te heelen. Dikwijls is dat heel wat, en haar familie zorgt wel dat het niet te weinig is, want in den regel is dat niet auders dan een douceurtje voor haar familie. Heeft men een brutalen schoonvader, of nog erger, een brutale schoonmoeder, dan valt gewoonlijk met de dochter niet te huizen, daar die geregeld wegloopt.

Natuurlijk, bedrijft haar man overspel, dan heeft zij niet alleen het recht, maar als fatsoenlijke vrouw ook de plicht, weg te loopen.

In andere gevallen wordt haar haar recht niet onthouden, evenmin aan haar familie, maar zij kan het langs wettigen weg zoeken.

\section{F. Over huisvredebreuk.}

$a$. Wanneer een man zijn vrouw slaat, of een vrouw slaat haar man, bedraagt de boete van $\mathrm{fl}$ tot $\mathrm{f} 20$, naar overweging der rechters. 
b. Wanneer een man zijn vrouw scheldt, of een vrouw scheldt haar man, mag de boete niet meer bedragen dan $\mathrm{f} 5$.

c. Wanneer echtgenooten elkander schelden, wordt geen boete opgelegd, maar het kamponghoofd vermaant hen.

Natuurlijk, nu de vrouw haar gewone verweermiddel "wegloopen" ontnomen werd, moest men bepalingen maken over deze materie.

Het verschil met den vroegeren toestand is dat de vrouw nu ook strafbaar is. Dat huiselijke oneenigheid nogal eens voorkomt, is geen wonder bij menschen die slechts zelden uit wederzijdsche genegenheid huwen.

Dat voor schelden gezegd wordt: "het mag daar niet boven gaan", komt, omdat elke vrouw een aparte gewoonte had om het schelden te beboeten. De boete werd vroeger uitsluitend betaald in "borden." $\mathrm{Nu}$, de een gelastte de borden op te stapelen, tot de stapel boven haar hoofd uitstak, een ander hakte eenvoudig een pisangboom om, legde de bladen straalsgewijs om zich heen, en gelastte nu de geheele, daardoor gevormde oppervlakte, met borden te bedekken.

Aan al dergelijke eischen moest voldaan worden.

$\mathrm{Nu}$ lat ook de nieuwe bepaling nog speelruimte voor individueele boetebepalingen, manr toch niet hooger dan $\mathrm{f} 5$.

d. Indien een man zijn vrouw verlaat, en langer dan twee jaar haar geen bericht zendt, en haar ook niet onderhoudt met kleederen en geld, kan die vrouw de zaak bij haar kamponghoofd aangeven, en scheiding aanvragen.

Aan die aanvraag mag echter niet dadelijk gehoor gegeven worden, eerst moet, zoo mogelijk, haar man worden teruggeroepen.

Indien hij niet wil terugkeeren tot zijn vrouw, mag zij van hem scheiden.

Maar indien de vrouw, alvorens wettelijk gescheiden te zijn, zich met anderen inlaat, zal zij wegens overspel vervolgd worden.

Om dit artikel goed te begrijpen, moet men den toestand eenigermate kennen. Dikwerf gaan jonge mannen dadelijk na de bruiloft, of ook wel eenigen tijd daarna weg, naar Batjan gewoonlijk, om door gom-copal te verzamelen, geld te verdienen.

Dikwerf toch worden, om den bruidsschat te betalen, groote schulden gemaakt, die afgedaan moeten worden. Natuurlijk gaat men ook wel naar andere deelen van den Archipel, maar gewoonlijk toch naar de Batjan-Obi-eilanden.

De, vrouw blijft nu alleen achter, jong, hartstochtelijk. Ook wel heeft zij kinderen, en moet nu maar zien aan den kost te komen, en aan brood voor allen. Is de man van het goede 
soort, dan stuurt hij zijn vrouw geld en kleederen, maar dikwerf doet hij dit niet, en blijft jaren achter elkaar weg. $\mathrm{Hij}$ zoekt natuurlijk in dien tijd zijn genoegen, leeft met andere vrouwen, etc. Komt hij terug dan is een schotel of sarong voldoende, om bij ziju vrouw als schaambedekking te dienen, en zijn vrouw moet hem nu maar weer goed ontvangen, alsof hij de trouwste echtgenoot ter wereld ware. De vrouw is echter al dien tijd door de schoonfamilie met argusoogen bewakt, of ook iets op haar aan te merken valt. $\mathrm{Bij}$ het minste wordt tegen haar een proces begonnen, en zij wordt veroordeeld tot het betalen eener hooge boete, haar familie moet den bruidsschat terug geven, etc.

In dien toestand tracht het artikel verbetering te brengen.

Natuurlijk gaat dat niet altijd gemakkelijk. Komt een vrouw klagen, dan is dat gewoonlijk omdat een ander al het oog op haar heeft laten vallen. De familie wil dan nog eerst trachten den weglooper terug te halen, en in den langen tijd die daarvoor benoodigd is, blijft het gedrag der vrouw zelden onberispelijk.

l. Indien een vrouw haar man niet goed verzorgt, of ook de kinderen van haar man, kan haar man haar aanklagen bij de Hoofden. Dezen zullen haar vermanen. Gaat zij voort met haar verkeerd gedrag, dan zullen de Hoofden haar veroordeelen tot eene boete groot f $5 .-$ en, indien ze daarma nog niet beter van gedrag wordt, zal haar man van haar kunuen scheiden en ziju betaalden bruidsschat terug ontvangen.

Ook dit artikel tracht een eind te maken an een verkeerden toestand. Het komt voor dat vrouwen, vooral die een tweede huwelijk aangaan en zelf kinderen hebben, slecht voor haar man zorgen, en zoo de mau ook kinderen heeft, slecht voor de stiefkinderen zijn. Zij geven ze dan geen eten, of auders oneetbare kostjes, willen geen tuin maken etc. Het gevolg is, dat de man zich naar zijn zusters begeeft zoo hij die heeft, of anders naar audere familieleden, om eten te vragen. Dadelijk is de vrouw er dan bij, om haar man aan te klagen, òf wegens overspel, zoo hij bij een vriendin at, òf wegens beleediging en veronachtzaming, zoo hij, met versmading van wat zijn vrouw klaar makte, het eten zijner zuster at. De bedoeling is duidelijk: zij zoekt zich van haar man af te maken en van hem te scheiden om redenen die zij hem ten laste legt, zoodat hij zijn bruidsschat kwijt is, en zij kan trachten een ander te vangen. Gewoonlijk gelukt dit bij de oude rechtspraak. Ik heb vrouwen gekend, die op die wijze reeds vijf mannen gehad hadden, maar nog nooit een bruidsschat hadden terug betaald.

Het artikel zoekt dezen toestand te wijzigen. 


\section{HOOFDSTUK V.}

\section{A. Over ech'tscheiding.}

a. Wanneer een vrouw overspel bedrijft, kan haar man van haar scheiden, met het recht zijn bruidsschat terug te ontvangen.

b. Wanneer een man overspel bedrijft voor de tweede maal, mag zijn vrouw van hem scheiden, terwijl haar bruidsschat niet terug betaald behoeft te worden.

Men ziet uit deze twee bepalingen, dat de man boven de vrouw bevoorrecht is, maar het is reeds veel, dat dit bereikt is.

Het Heidensche recht kent de vrouw nooit het recht tot scheiden toe wegens overspel van haar man. Voldoet deze de opgelegde boeten, dau heeft de vrouw nooit keus, zij is immers zijn eigendom!

c. Wanueer een man of vrouw steelt, of wel getroffen wordt door een Gouvernementsvonnis, wegens een groot vergrijp, kan de echtgenoot (e) scheiden.

Heeft de vrouw gefaald, dan moet haar bruidsschat terug betaald worden, is de man de schuldige partij, dan is zijn bruidsschat vervallen.

Wat tijdens het huwelijk door beiden verkregen is, wordt geleidelijk tusschen partijen verdeeld.

Hier is dus sprake van onteerende handelingen. "Stelen" is bepaald eene schande. Een vrouw die steelt, wordt door haar man dadelijk verlaten, daar helpt geen betalen aan, en ook wel omgekeerd. Verder wordt gedacht aan zware vonnissen, kettingstraf, ballingschap, etc.

d. Wanneer iemand wenscht te scheiden, moet hij van dat voornemen kennis geven aan den Zendeling. Deze onderzoekt of de aangevoerde redenen geldig zijn, en staat het verzoek toe, of weigert het, naar bevind van omstandigheden.

De scheiding wordt niet voor goed uitgesproken vòr drie maanden na het daartoe gedane verzoek.

Indien tijdens die drie maanden, de echtelieden niet weer te zamen geweest zijn, en bij hun voornemen volharden, zal de scheiding worden uitgesproken.

Het zou uit het bovenstaande kunnen schijuen, alsof de Zendeling de persoon was, die scheidt. Dit is echter niet zoo. Scheiding is altijd het gevolg van een rechterlijk vonnis, en 
de Zendeling doet dus niet anders, dan daarvan anteekening houden en zorgen dat alleen die huwelijken ontbondeu worden, welke volgens deze adat daarvoor in aanmerking komen.

Het stellen van een termijn was wel noodig, omdat het gebeurt dat de lieden koelbloedig willen scheiden, maar na eenigen tijd kalmeeren, en dan weer op hun besluit terugkomen.

Bij de Heidenen is scheiden een heel kort proces. Gaat men voor een zaak voor den rechter, d. w. z. wanneer de vrouw zich wil laten scheiden, dan neemt zij een vuurtangetje mee. Zoo'n tangetje is een plat bamboestaafje, in het midden gekuakt, en dan dubbel gevouwen. De rechter neemt dit, breekt het doormidden, geeft elk der echtelingen de helft, en de scheiding is een voldongen feit. Wil de man scheiden, dan is het nog gemakkelijker. Hij zegt eenvoudig tot de vrouw : "ik scheid je", en gaat weg, of anders gaat zij weg, omdat zij te beschaamd is, om na die woorden nog te blijven, en alles is afgeloopen. Dat de man na eenigen tijd terugkeert, gebeurt nog al dikwerf.

$c$. De kinderen, die tijdens het huwelijk geboren zijn, worden an de niet schuldige partij gegeven.

Men zie het volgende artikel.

B. Over HET VERDEELEN DER KINDEREN EN GOEDEREN BIJ SCHEIDING.

$a$. Indien een vrouw wil scheiden om andere, dan de bovengenoemde wettige redenen, moet zij haar bruidsschat terug betalen, vermeerderd met eene boete, om vrij te worden.

- Voor het district Galéla is die boete f 18 ; voor de districten Tobèlo, Kau en Loloda $\mathrm{f} 24$.

Van de goederen welke haar man behooren, krijgt zij niets, maar van het haar persoonlijk behoorende, alsmede van de opbrengst van haar tuin, en van het werk harer handen (matten en dergelijke) krijgt zij de helft.

De kinderen verblijven aan den man.

$b$. Wanneer een man op dezelfde wijze van zijn vrouw wil scheiden verbeurt hij zijn bruidsschat, of, zoo hij die nog niet betaald heeft, moet hij zijn vrouws maagdom betalen.

De goederen worden gelijkelijk tusschen beide partijen verdeeld.

De kinderen blijven bij den vader, zoo deze den bruidsschat reeds betaald heeft, is die nog niet betaald dan blijven zij bij de moeder.

Betaalt de man alleen den prijs van den maagdom, dan zullen de kinderen tusschen beide partijen gelijkelijk verdeeld worden.

Is slechts één kind aanwezig en is het een meisje, zoo zal 
later haar bruidsschat tusschen partijen gelijkelijk verdeeld worden; is het een jongen, dan zal hij afwissselend bij zijn vader en moeder vertoeven tot zijn trouwen, als wanneer hij voorgoed diengene volgt, die zijn bruidsschat betaalt.

Men ziet hieruit, dat de man boven de vrouw bevoorrecht is. Hem wordt meer toegesproken dan haar. Ook verliest hij niet het recht op de kinderen, die hem zelfs geheel volgen zoo hij hun bruidsschat betaald heeft. Ook kan hij, zoo hij nog niet betaald heeft en de kìnderen dus an zijn vrouw verblijven, ten allen tijde zich het recht op zijn kinderen toeëigenen, en die van de moeder weguemen, door zijn bruidsschat te betalen. Het is niet juist, dat de toestand tijdens de scheiding beslist over het lot der kinderen. De vader kan ze te allen tijde krijgen, dus heeft hij er het recht op, en de moeder mag ze alleen hebben als onderpand voor haar nog niet betaalden bruidsschat, zoo n.l. de vader oorzaak is der scheiding. Is zij dat zelf dan krijgt zij niets, kortaf. Zij gaat bijkans ledig uit.

Het is duidelijk, dat hîer sprake is van moed willige verlating, niet van verlating wegens overspel. Het is dus scheiding wegens wederzijdsche antipathie.

De bepalingen, hiergenoemd, gelden ook voor de Heidenen, 14 het Christendom heeft er niets aan veranderd.

Het geld dat de vrouw nog boven haar bruidsschat betalen moet heet: "onkostengeld" of "gewoontegeld".

Het is een som om den man schadeloos te stellen voor de kosten, die hij nog boven den bruidsschat gemaakt heeft. Dikwerf zijn de kosten vrij aanzienlijk, zoodat de man toch nog al wat schade heeft.

\section{HOOFDSTUK VI.}

Over overspel.

$a$. Wauneer een gehuwd mau overspel bedrijft met een jong meisje, zal hij f 20 boete betalen en het meisje zal ook $\mathrm{f} 20$ boete betalen.

Indien hij dit meisje wil verlaten en terugkeeren tot zijn vrouw, zal hij haar ook f 20 moeten betalen, om haar schaamte te dekken.

Indien hij zijn vrouw wil verlaten, zal hij van haar kunnen scheiden en zijn bruidsschat verliezen.

Volstrektelijk niet, zal hij twee vrouwen mogen hebben.

Deze bepaling is ook juist als bij de Heidenen, alleen zijn de boeten wat verlaagd, zoodat zij nu binnen het bereik vallen. 
De vrouw mag er geen oorzaak van scheiding van maken. Wel loopt zij dadelijk weg, maar zij moet terug komen, als de zaak berecht is, en haar man haar nog bovendien het geld tot dekking van hare beschaamdheid (over het gedrag van haar man) geeft.

Wil de man niet terugkecren, dan ontvangt zij wel het haar komende deel van de boete, maar anders niet.

Men begrijpt, dat het nog al eens voorkomt, dat ecn oudere vrouw op die manier geloosd wordt, om voor een jongere plaats te maken. Polygamie kent het Heidendom ook eigenlijk niet. Wel mocht vroeger een man, nevens zijn Tobèloreesche vrouw, slavinnen van vreemden stam tot bijwijven hebben, maar toch niet zonder toestemming der wettige vrouw, en onder verplichting evenveel nachten bij de eigen vrouw, als bij de slavinnen door te brengen. Nu komt polygamie nog heel enkel voor, maar sterft vanzelf uit. Immers men heeft nu geen slavinnen meer. Wel wil deze of gene, ook onder de Heidenen vooral, het nog eens probeeren, maar het algemeen gevoelen is er tegen, en de vrouw loopt dadelijk weg als haar man zich met een ander ophoudt, en keert niet terug, zoolang de betrekking met de vreemde vrouw niet voor goed verbroken is.

Wel is dus bij de Heidenen de huwelijksband heel onvast, maar toch heerscht monogamie.

b. Wanneer een gehuwd man overspel pleegt met eens anders vrouw, moeten beiden de onder $a$ genoemde boete betalen, en bovendien moet de man de schade vergoeden aan den man der overspelende vrouw. c. Wanneer een ongehuwd man overspel bedrijft met een gehuwde vrouw, is de boete als bepaald onder $b$.

Deze bepaling is ook reeds als zoodanig lang onder de Heidenen geldende. Vroeger was de bepaling, dat elke man het recht had om dengene te dooden, die hem onteerde door zijn vrouw te verleiden.

Onder de Medole-stam, waar eenige jaren geleden Gouvernements-invloed nog niet doorgedrongen was, kwam dit ook zeer veel voor. Bijna alle moordgevallen kunnen hieruit verklaard worden. $N u$ is het $z o o$ dat, zoodra zulk een zaak bekend wordt, de familie van den beleedigden man de zaak aangeeft, nooit den man zelf, die mag zijn recht alleen met het wapen zoeken.

De Hoofden moeten zich nu, zoo mogelijk, dadelijk van den overspeler verzekeren, opdat deze niet ten offer valle aan de wraak van den beleedigden echtgenoot. Is het vonnis uitgesproken, en de boete betald, dan is de zaak in orde. De beleedigde man krijgt zijn bruidsschat terug met alle uitgaven, die hij voor zijn vrouw gedaan heeft, aangezien zijn vrouw voor hem onbruikbaar geworden is. Natuurlijk wordt dit bedrag zoo hoog mogelijk gerekend. 
Het kwam eenmaal voor dat een man zijn ontrouwe vrouw, nadat hij met veel drukte zijn geld teruggeëischt had, weer tot zich nam. Daarover werd algemeen schande gesproken. Door zijn vrouw weer tot zich te nemen, bewees die man dat zij door het voorgevallene voor hem niet onbruikbaar geworden was, en hij had dus ook geen schadevergoeding mogen eischen.

d. 1. Indien tezamen betrapt worden een jongeling met een jonge dochter, of een weduwnaar met een jonge dochter, of een jongeling met eene weduwe, zullen beiden $\mathrm{f} 5$ boete betaleu.

2. Echter, indien de vrouw geschreeuwd heeft toen de man tot haar kwam, en de man wordt gegrepen, dan zal hij alleen f 5 boete betalen.

3. Indien een ongehuwde vrouw zwanger wordt, en den naam nocmt van dengene met wien zij gemeenschap gehad heeft, zal van dien man geëischt worden, die vrouw te huwen. Weigert hij haar te trouwen, dan moet hij f 30 schadevergoeding betalen an den vader der vrouw.

4. Is de bewuste man geen Christeu, maar een Heiden, dan zal de betaling geregeld worden naar de Heidensche adat.

5. Indien de man de beschuldiging der vrouw ontkent, en beweert dat meer mannen met haar gemeenschap gehad hebben, zoo moet hij de namen dier mannen noemen, en getuigen bijbrengen, om zijn beweren te staven.

De bepalingen alinea 1 en 2 zijn nieuw. De Heidensche adat kent geen overspel, behalve dat hetwelk gevolgen heeft. Het onzedelijke begint pas bij de zwangerschap. Op losheid van zeden bij jongelui staat zelfs geen onbillijkend oordeel. Natuurlijk kon dit niet zoo blijven, en vandaar deze bepalingen.

Het is voor eene veroordeeling niet noodig, dat de lieden op geslachtsgemeenschap betrapt worden. De lieden oordeelen heel wat scherper dan wij. Komen twee jongełù, of wel een mannelijk en vrouwelijk persoon, geen-echtelieden zijnde, tezamen vau een eenzame plaats, of van denzelfden weg uit liet bosch, dan is het overspel reeds bewezen en het vonnis wordt geveld. Men kan hieromtrent alleen zeggen: 't volk zelf wect het best hoe zijn zeden zijn.

Alinea 2 wordt door de billijkheid geëischt. Bij de open huizen is het natuurlijk heel goed mogelijk, zonder voorkennis of tegen den wil eener schoone, in haar slaapvertrek te dringen. Gewoonlijk ontkomt, bij gerucht harerzijds, de eerrander in het nachtelijk duister.

Alinea 3 is ook aldus bij de Heidenen in gebruik. Alleen is de boete daar wel eens wat minder. Dat de betaling aan 
den vader der vrouw komt, wijst uit wat het doel der boete is. Deze heet: "o moholehe ma idja" "prijs des maagdoms", en wordt aan den vader betaald, omdat door het verlies van den maagdom, de bruidsschat der jonge dochter aanzienlijk minder wordt.

Betreft het eene weduwe, of eene vrouw die reeds kinderen heeft, dan wordt de eisch ook lager gesteld.

Wordt in den eisch tot trouwen toegestemd, dan eischt een krachtig kamponghoofd nog eerst de boete wegens ongeoorloofde gemeenschap à f 5 , waarop hij dan ook recht heeft, omdat door de zwangerschap een vroegere ongeoorloofde gemeenschap bewezen wordt.

De boete wegens zwangerschap ${ }^{\bullet}$ zelf wordt dan echter natuurlijk niet betaald. Voor de vrouw vindt men geen schadeloosstelling noodig, immers zij gewint een kind, dat is schadeloosstelling genoeg.

Dat over deze zaak heel veel, moeilijk te beslissen, processen gevoerd worden is wel te begrijpen. Dikwerf worden ze alleen door een eed beslecht.

Alinea 5 is ook nieuw, in zooverre dat de vrouw toegelaten wordt, zich tegen de beschuldiging te verweren. Heel dikwerf is die waar, zoodat men bij de Heidensche adat gewoonlijk maar zwijgt, als deze beschuldiging uitgesproken is. De Christelijke kon dat echter niet toelaten. (Zie 't volgende artikel).

e. Indien een ongehuwde vrouw zwanger wordt, en niet met zekerheid den vader vau haar a.s. kind weet aan te wijzen omdat verschillende personen met haar gemeenschap gehad hebben, zal zij veroordeeld worden $\mathrm{f} 25$ boete te betalen wegens hoererij.

Dit artikel is nieuw. De Christelijke maatschappij kan natuurlijk hoererij niet in haar midden dulden. Ook de Heidensche duldt die liever niet, maar zij heeft deze bepaling niet in haar adat.

$f$. Indien een man overspel bedrijft met de vrouw zijns broeders, of met de zuster zijner vrouw, zal hij de reeds genoemde boeten dubbel betalen.

Dit is niet, omdat men hierin wat bloedschendigs ziet, maar omdat het opgevat wordt, als een grove schending van vertrouwen. De families wonen dikwerf tezamen in één huis, en men vertrouwt elkander op dit punt. Zouder dat vertrouwen zou natuurlijk de samenleving heel gewoon onmogelijk worden, en dit is de reden dezer verhoogde boeten.

g. Bloedschande kan slechts te Ternate berecht worden.

Dit is ook wel wat nauw opgevat. Vroeger wis het zoo.

Men zegt dat heel vroeger, in oude tijden dus, bloedschenners in den krater van den vulkaan van Ternate geworpen werden. 
Bij natuurrampen, vooral aard- of zeebevingen, denkt men beslist aan het gepleegd ziju van bloedschande.

Ik woonde eenmaal het volgende bij: een jougmeusch was gehuwd met zijn halve zuster. De jongelui waren altijd als hroer en zuster beschouwd, zoodat zij ook tezamen in één huis geleefd hadden. Het bleek echter plotseling, dat zij gemeenschap met elkaar hielden.

Een dorpshoofd, wiens zedelijk gevoel niet heel hoog stond, maakte deze zaak in orde door een boete te ontvangen, maar, om zich nu toch voor de mogelijke gevolgen te vrijwaren, wierp hij van de ontvangen som $\mathrm{f} 0.50$ in zee, opdat deze, daardoor tevreden gesteld, niet zou gaan beven.

Of men in de zaak op zichzelf overtreding gezien heeft, geloof ik niet. Het ligt ook in den aard der zaak. Er wordt nicmand door beleedigd en dus heeft ook niemand aanleiding tot eenige klacht. De strenge bevelen te dezen opzichte, zullen wel van Ternate uitgegaan zijn.

Ik heb ook nog een ond soldaat gekend, die beslist met zijn eigen zuster leefde. Men voud dit vies, maar makte geen rechtszaak. Natuurlijk niet! Wie moest klagen? Was de een of andere uatuurramp gevolgd, dan had men wellicht de luidjes naar Ternate gebracht, teueinde het land van de oorzaak dier ramp te verlossen.

\section{HOOFDSTUK VII.}

\section{Over diefstal.}

a. Indien gestolen wordt uit een huis of afgesloten ruimte, en de waarde van het gestolene niet meer bedraagt dan f 20 zal de boete bedragen van f 5 tot f 48 , naar overweging der rechters, terwijl het gestolene moet worden teruggegeven of vergoed.

b. Indien iets gestolen wordt, dat slechts voor het nemen is, en de waarde vau het gestolene bedrangt niet meer dan f 20, zoo zal de boete bedragen van f 5 tot $\mathrm{f} 25$ naar overweging der rechters, terwijl het gestolene moet teruggegeven of vergoed worden.

$c$. Indien gestolen wordt uit tuinen, en de waarde van het gestolene bedraagt meer dan $f l$, dan zal de boete bedragen van $f 10$ tot f 48 naar overweging der rechters, terwijl het gestolene teruggegeven of vergoed moet worden.

d. Indien het bedrag van het uit een tuin gestolene niet komt tot f l, dan zal de zaak berecht worden als cen geval van ondeugd.

e. Indien de warde van het gestolene meer bedragt dan f 20 kan de zaak alleen te Ternate berecht worden.

7e Volgr. IX. 
Heel veel komt diefstal niet voor. Het is in de Alfoersche maatschappij eene schande, dief te zijn. Echter zit kleptomanie bepaald in sommige families, die dan natuurlijk ook geregeld gemeden worden, al brengt ook de hoffelijkheid mede dat men van zijn verachting niet al te openlijk blijk geve. 'Loo we gezien hebben is diefstal een geldige reden tot echtscheiding. Gewooulijk wordt een diefstal niet ontdekt, d.w. z. de daders ervan niet. Het speurstelsel is nog niet in toepassing. Jiefstal uit huizen wordt zwaar gestraft. Men bedenke dat de huizen gewoonlijk geheel open zijn, en soms voor geruimen tijd verlaten worden. Het is nu niet geoorloofd een huis binnen te treden zonder verlof van den eigenaar, en een fatsoenlijk man komt dus niet in het onbewoonde huis van een ander. Diefstal uit een huis staat dus gelijk aan diefstal met braak.

Laat men voorwerpen buiten rondslingeren zonder deze in huis te leggen, dan wordt men geacht ten deele zelf schuld te zijn aan den diefstal en daarom is dan ook de straf miuder.

Een zwaar vergrijp is het echter, vruchten uit tuinen te stelen. Dat hierbij de waardegrens genoemd wordt is om misbruiken te voorkomen.

Men is n.l. dikwerf gewoon, wauneer men met elkander verwant of bevriend is, een stengel suikerriet, een blad tabak etc. van elkaar te nemen. Niemand beschouwt dit als diefstal. Men weet, men heeft daartoe bij de andere partij ook wel het recht. Wordt men nu echter op elkaar boos, dan worden dergelijke dingen plotseling tot vergrijpen waarover men zich beklaagt, en dikwerf volgt dan een aanklacht en bestraffing wegens diefstal, waar heelemaal niet het opzet tot stelen geweest is. Dit misbruik wordt door alinea $d$ tegengegaan. Ook ziet dit op het stelen van vruchten. Dat kan nu ook niet meer als diefstal veroordeeld worden, aangezien de gestolen vruchten gewoonlijk niet de warde van f l hebben. Eene veroordeeling wegens ondeugd volgt dan wel, maar die is niet zoo erg als eene wegeus diefstal, en ook niet zoo beschamend.

De laatste alinea beteekent natuurlijk, dat diefstal van grootere sommen, niet onder de competentie van den inlandschen rechter valt.

\section{HOOFDSTUK VIII.}

\section{Over brands'tich'ting.}

a. Indien iemand door onoplettendheid eens anders goed verbrandt, moet hij de angerichte schade vergoeden.

$b$. Indien iemand eeus anders boel verbrandt, niet door nalatigheid maar met boos opzet, kan die zaak alleen te Teruate berecht worden. 
Onopzettelijke brandstichting ontstaat meest, doordien men per ongeluk de alang-alang in brand steekt. Men wandelt, maar houdt een brandend stuk kool in de hand, om voortdurend de sigaret aan te steken.

Is de tabak op, dan laat men het hout vallen, gewoonlijk in de alang-alang. De wind blaast het aan, en onder gunstige (of ongunstige) omstandigheden, vliegt het alang-alangveld in brand, en daarmede verbranden dikwerf ook rijsttuinen, tuinhuizen, etc. Het spreekt echter vanzelf, dat in deze gevallen hoogst zelden de dader gevonden wordt.

Ook gebeurt het dat men zijn tuin brandt, d.w.z. de daarin liggende takken en boomen, en 's avonds dat laat smeulen. De avondwind wakkert het aan, en nabijgelegen tuinen of boschaanplantingen worden vernield. De oorzaak is dan gewoonlijk heel goed na te gaan, en de straf volgt dan ook volgens adat.

Opzettelijke brandstichting is zoo iets ongehoords, dat men zich dat niet kan voorstellen, vandaar dat het ook niet onder de competentie van den Inlandschen rechter valt, maar tot de zwaarste misdaden gerekend wordt.

\section{HOOFDSTUK IX.}

\section{Over vechten EN VERWONDINGEN.}

a. Wanneer twee of meer lieden met elkaar vechten, zal ieder hunner f 3 boete betalen.

Indien wonden of builen geslagen zijn, bij den een meer dan bij den ander, dan zal de toebrenger van die wonden of builen beboet worden, naar gelang der grootte der wonden of builen, die hij heeft toegebracht.

De eerste bepaling is eigenlijk nieuw. Men heeft vechten en stompen nooit eene overtreding gevonden op zichzelf.

$N u$ acht men het verbreking van den dorpsvrede, en het wordt dus gestraft, 't geen ook wel mag om de ruwheid van zeden wat te temperen.

De laatste bepaling is eigenaardig. Wegen de wonden of builen tegen elkaar op, dan wordt de zaak in orde gerekend. Alleen als er groot verschil is, is er sprake van beboeten. Gewoonlijk is dit alleen, als een der partijen zich van onwettige middelen bediend heeft, een boksbeugel of dergelijke. Heeft dat niet plaats gehad, dan loopt alles in der minne af, d.w.z. de boete moet betaald worden voor het vechten en daarmede uit.

b. Wanneer iemand een ander lichamelijk beleedigt, zoodat de litteekens op het lichaam van den beleedigde zichtbaar zijn, zal de beleediger gestraft worden met ecne boete van f 3 tot f 30 , naar overweging der rechters. 
Men had vroeger hiervoor een heel tarief. Voor een tand f 20 , voor een vinger zooveel, voor eem striem zooveel, etc. Natuurlijk dat dit nog al eens tot dwaze rechtspraak aanleiding gaf. $N u$ is de boete gewoonlijk niet heel hoog.

$c$. Indien twee jongelui vechten om der wille van een meisje, en dit meisje van den eenen jongeling, met medeweten van haar ouders presenteu aangenomen heeft, zoodat hij haar wettige bruidegom is, maar zij toch aan den auderen gunsten heeft betoond, zoo zal dat meisje de boeten betalen voor het vechten. Maar ontstaat de vechtpartij, omreden de bruidegom alleen maar jaloersch is op een ander jongeling zonder dat het meisje hiertoe aanleiding gaf, dan zal de vechtende zelf zijn boete betalen.

Natuurlijk dat om deze redenen nog al eens gevochten wordt. $\mathrm{Nu}$ vond men dat vroeger heel onschuldig, als het alleen maar bij vechten bleef. $\mathrm{Nu}$ echter het vechten als zoodanig straf baar is gesteld, is men natuurlijk naar de oorzaak gaan zoeken, en vond haar dikwerf in de meisjes zelf.

d. Indien iemand levensgevaarlijk verwond wordt, kan de zaak alleeu te Teruate berecht worden.

Dit valt dus niet meer onder de competentie van den inlandschen rechter.

\section{HOOFDSTUK $\mathrm{X}$.}

\section{OVER MOORD.}

Moord kan alleen te Ternate berecht worden.

Dit is natuurlijk niet altijd aldus geweest. Men heeft vroeger heel goed zware verwondingen en moord berecht, natuurlijk alles met het betalen van een boete. Misschien heeft echter de idee, om deu moordenaar aan de bloedwraak te onttrekken, er wel toe bijgedragen de lui naar Ternate te doen brengen.

Gezegd moet worden, dat het brengen naar Teruate sinds daar de Rijksraad zetelt, tamelijk ongevaarlijk is. Het leveren van het bewijs voor moord valt hoogst moeilijk, en ook hast al de gevallen welke, tijdens mijn hierzijn berecht werden, waren "koerang terang", nict voldoende helder, en eindigden dus met vrijspraak. Het is ook niet van de lui te verwachten, dat ze voor zoo'n rechter, die hun taal niet spreekt enz., waarheid zullen spreken, of eerbied hebben voor het afleggen van een eed. Men meent dat die eed klemt, wannecr hij op inlandsche wijze wordt afgelegd, maar vergeet dat die alleen van kracht is in het land, afgenomen door de eigen hoofden 
of oudsten. Te Ternate hooren de voorvaderen er niets van, die wonen te Tobèlo, en zijn toch niet alomtegenwoordig!

$N u$ wordt moord ook door den Civiel-gezaghebber berecht. Dat dit echter ook tot vreemde dingen aanleiding geeft, bleek onlangs, toen door een Civ.-gezagh. ad interim eenige moordenaars gevangen werden en opgezonden naar Ternate. De lui waren daar verwonderd over. Ze kwamen met, ik meen, f 90 aandragen om die te betalen als boete. Ze hadden een par jaar geleden ook een moord gepleegd, toen aan den Civielgezaghebber f 90 betaald en hadden die som er natuurlijk wel weer voor over.

\section{HOOFDS'TUK XI.}

\section{Over bedreigen.}

a. Wanneer men iemand bedreigt met woorden, bedraagt de boete $\mathrm{f} 6$.

b. Wauncer men iemand bedreigt met wapens, bedragt de boete f 12.

Het is duidelijk, dat deze bepalingen niet overbodig zijn. Het komt toch soms al heel gauw tot daden, en daarom is het goed dat ook het voornemen, of het uitspreken van het voornemen strafbaar is. Vroeger was deze boete nog veel zwaarder, onzinnig zwaar zelfs.

c. Indien iemand in toorn zijn slaapbank, waterbamboe, pisangboom of vruchtboomen stuk hakt, en daarbij den naam noemt van den persoon op wien hij boos is, zal hij een boete betalen van $f 3$ tot $f 30$ naar overweging der rechters.

Deze bepaling mag vreemd lijken, zij is toch volkomen Alfoersch. Iemand wordt boos op een ander bij het hooren van 't een of ander, en koelt nu zijn boosheid door iets te verniclen, slaapbank, watervat, etc. Het is een heele gewone manier van doen, en wij zouden zeggen: tamelijk onschuldig want de persoon in kwestie voelt er niets van. Men kan het opvatten als een bedreiging tegen het leven gericht, maar dat is het ook niet, want het wordt nooit door moord gevolgd.

Toch is meu er ontzettend gevoelig voor. De grondgedachte zal wel zijn, dat het een soort handeling is waardoor iemands geest getroffen kan worden, of die door sympathie iemands dood kan berokkenen. $N u$ zegt men: de wil was er om die of die te dooden of te verwonden. Men mag dien wil niet hebben, en dus wordt men daarvoor gestraft. Ik zag eenmaal iemand, die een sirihrauk waarover men twistte stuk gehakt had, vounissen, alsof hij manslag begaan had. Op mijn vraag waarom dat zoo zwaar gestraft werd, aangezien de sirihrank hoogsteus 20 cent waard was, en dan nog in elk geval voor de helft het eigendom was van den man die hem vernielde, 
werd mij gezegd, dat duidelijk gebleken was dat de woede van den man zóó groot was, dat hij tot doodslag in staat geweest was, en dus mocst hij wel als moordenaar gevonnisd worden. De wil werd dus eenvoudig voor de daad genomen.

\section{HOOFDSTUK XII.}

\section{Over he't schelden.}

Wanneer iemand een persoon of een dorp scheldt met woorden of teekenen, zal dit feit gestraft worden met cen boete van $\mathrm{f} 2$ tot $\mathrm{f} 20$ naar overweging der rechters.

Men verstaat onder "schelden" ook wat anders dan wij. Het is in hoofdzaak het gebruiken van vuile, onkiesche woorden en aanduidingen; ook iemand "dief" noemen. Men kan evengoed met teekenen als met woorden schelden. Er zijn allerlei bladeren en bloemen, wier namen eenigermate met onkiesche woorden, namen van geslachtsdeelen etc. overeenkomen, of in wier namen ook meer gedeelten van zulke woorden voorkomen, en die daarom een vaste beteekenis als scheldteeken hebben gekregen. Ook zijn er wel bloemen en planten welker namen voorkomen in den eersten regel van een schendend rijmpje, en die daarom dat heele rijmpje vertegenwoordigen. Nog makt men allerlei vuile teekens, een maunelijk of vrouwelijk geslachtsıleel voorstellend b.v.b. $\mathrm{Nu}$ kan men zooiets voor den toegang tot iemands woning hangen, op de slaapplaats van een meisje * leggen, etc. Men scheldt dan een huisgezin of persoon. Men kan het echter ook aan den ingang van een dorp stellen, of aan de aanlegplaats, en daardoor de beleediging tot een heel dorp uitstrekken. Het is in de meeste gevallen niet moeilijk alsdan den beleediger uit te vinden, daar men wel weet wie een wrok heeft.

Wat het schelden tegen personen betreft, was het vroeger nogal moeilijk daarin recht te spreken, daar er geen bepaalde boete op stond, en elk maar eischte, naarmate hij zich beleedigd voelde. Vooral vrouwen waren op dit punt heel prikkelbaar en heel kostbaar, daar elk er haar eigenaardige gewoonte op nahield, om de beleediging te doen verzoenen. De dolste eischen werden dau gesteld, maar er moest aan voldaan worden, wanneer men maar beweerde: zoo is de adat. Aan dergelijken willekeur is nu natuurlijk een eind gemakt.

\section{HOOFISTUK XIII.}

\section{Over laster.}

Wie iemand lastert, door hem ten onrechte te beschuldigen van handelingen, die niet goed of niet geoorloofd zijn, zal betalen eene boete van f 8 tot f 24 nar overweging der rechters. 
Bij "laster" moet in 't bijzonder gedacht worden aan het iemand beschuldigen van overspel of tooverij. Dat zijn de zwaarste vergrijpen waarover de processen gevoerd worden, vooral het cerste. Natuurlijk is er heel weinig noodig, om zulk een lasterproces in gang to brengen. Ook komt het natuurlijk voor, dat de zaak waarvan men iemand beschuldigt, niet te bewijzen is, ook al is die waar, en wanneer dan de beschuldigde zich door cen zuiveringseed (zie Hoofdstuk XXXIII) zuivert, moet de beschuldiger natuurlijk de boete voor laster betalen, want is een proces eenmaal begonnen, dan moet er ook betaald worden, òf door den beschuldigde, òf door den beschuldiger.

\section{HOOFDSTUK XIV.}

\section{Over bedrog.}

a. Hij die iemand bedriegt met woorden of daden, niet volbrengt hetgeen door hem beloofd was, betaalt eene boete van f 1.60 tot f 16. - naar overweging der rechters.

Men kan de lieden nu juist niet van al te groote waarheidsliefde beschuldigen. Zij zien feitelijk in bedrog geen $\mathrm{kwaad}$. Een handig bedrieger kan zelfs beroemd worden. Gelukt het, cen heel dorp of een heel district in rep en roer te brengen door een verzonnen praatje, dan verkneukelt men zich van pret. Een bepaling als deze is dus feitelijk niet uit den volksaard voortgekomen, tenminste niet uit den Heidenschen. De Christenen vinden haar echter zeer noodig.

b. Indien iemand een voorschot ontvangt voor eenig werk, of voor iets dat door hem geleverd zal worden, en hij niet voldoet aan zijn belofte, maar het voltooide of het te leveren stuk werk verkoopt aan een ander, moet hij het dubbele van het ontvangen voorschot terug betalen.

c. Indien iemand een voorschot ontvangt om eenig stuk werk te maken of eenig werk te verrichten, en hij dat werk niet maakt of niet komt om te werken, zal het voorschot niet teruggegeven worden, zonder de behoorlijke boete daarbij gedaan.

d. Indien voorschot gegeven is voor eenig werk, en dat werk is behoorlijk in gereedheid gebracht, maar de besteller weigert het te ontvangen, dau zal de vervaardiger het terug kunnen nemen, zonder het ontvangen voorschot terug te betalen.

Dit betalen van voorschotten moge zonderling lijken, het is het toch in werkelijkheid niet. Het is eenmaal gewoonte dat men bijna niets doet, zonder vooraf de gedeeltelijke of geheele betaling te ontvangen. De omstandigheden brengen dat 
zoo mee. In den regel heeft men voor zijn behoeften volkomen genoeg en dau werkt men niet voor een ander. Plotseling cchter heeft men voor het een of ander geld noodig, om ecn boete of een bruidsschat te betalen of te helpen te betalen, om 't een of ander te koopen, of wel men wordt aangemaand een oude schuld af te doen, etc. Men heeft dan plotseling geld noodig en tracht dat nu van den cen of ander los te krijgen, onder belofte het een of auder te zullen afleveren; ten minste, zoo men het niet leenen kan; dit probeert men eerst. Gaat dit niet, dan wil de een bouwmaterialen halen, planken of balken, de ander dakbedekking leveren, een derde zich als knecht of roeier verhuren, alles onder voorwaarde, dat meu dadelijk het geld krijgt. Dikwerf is dit de eenige weg om materialen of werkvolk te krijgen. Handelaren maken natuurlijk van die omstandigheden gebruik om werkvolk te krijgen, dat zij anders moeilijk krijgen kunnen. Zij trachten eerst de lui in de schuld te brengen; om dan later die schuld door dwang te innen, en zoo die niet voldaan wordt, den schuldenaar in zijn dienst te nemeu, voor ecu veel te laag loon natuurlijk. Echter is het ook wel te begrijpen, dat de betrokkenen, nadat het geld ontvangen is, niet heel veel lust hebben den beloofden arbcid te presteeren en de goedmoedige geldschieter heeft tot loon gewoonlijk heel veel last om het werk gedaan te krijgen, waarvoor hij het geld uitgaf. Het is wel te begrijpen, dat in een Heidensche matschappij vreemdelingen het meeste last daarvau hebben. Die staan buiten het stamverband en hebben dus ook niet de cen of andere wrak der voorvaderen tot hun beschikking. Is nu, zooals het vroeger altijd was, de toestand zò̀ dat er geen wettelijke macht is die dringend optreedt, dan zijn er heel wat personen, die er geregeld op azen zich ten koste van domme vreemdelingen van geld te voorzieu, maar nooit iets daarvoor te presteeren. De bepalingen ziju dus voor een volk, dat altijd voorschot wil ontvangen, niet overbodig.

Natuurlijk is het noodig, dat bij een beter ordenen der maatschappelijke toestanden, dat voorschot geven ophoudt, maar daartoe moet eerst meer geld in circulatie komen, en een geregelden toestand ontstaan, een maatschappij waarin elk producent is.

Door de Zending zal die betere toestand wel komen, zoo het Evangelie doorwerkt, maar het is nu nog niet zoo.

\section{HOOFDSTUK XV.}

\section{Over HE'T LEENEN.}

$a$. Wanneer iemand iets geleend heeft, ouder belofte van het na zekeren tijd terug te zullen geven en hij zijn belofte daaromtrent 
niet houdt, zal hij $\mathrm{f} l$ boete betalen, en verder zal hij huur betalen voor het geleende voorwerp, gedurende den tijd, dat hij het lauger (dan geoorloofd was) gebruikt heeft, naar bepaling der rechters.

Hier is voornamelijk gedacht aan het leenen van voorwerpen, vooral vaartuigen. Eencrzijds gebeurde het, dat men die leende en dan maar hield, zoodat de eigenaar zeer ontriefd was en dan zelf het terug kon gaan halen, soms het nict eens krijgen kon als hij het noodig had. Recht was daarvoor niet te vinden.

Aan den anderen kant bestond het euvel, dat iemand b. v. cen vaartuig geleend had, en het door force majeure, niet kon teruggeven op den juisten tijd; alsdan weigerde de cigenaar het terug te ontvangen, maar eischte eenvoudig een buitensporig hoogen prijs voor het geleende vartuig. Dit artikel stelt in deze heel goed perk en paal, door eenerzijds een boete te bepalen voor het over den tijd houden, daarenboven zelfs nog huur van het voorwerp te eischen, maar alles naar overweging der rechters, zoodat nu van willekeur, noch bij leencn, noch bij outleenen, sprake zijn kan.

b. Wie goed ontleent, is verplicht na een jaar het dubbele aạ den leener terug te geveu. Geeft hij het alsdan niet terug, zoo zal elk jaar, dat hij met de betaling wacht, de schuld verdubbelen. Echter zal de leener verplicht zijn, elk jaar de schulả van den ontleener te eischeu. Laat hij dit na, dan zal hij, ook na langeren termijn, niet meer dan het dubbele van het geleende kunnen eischen.

Dit ziet natuurlijk op zaadrijst. Het is de oude bepaling, maar de laatste zinsnede is nieuw, en dient om een groot euvel te voorkomen. Het gebeurde bv. zóó: De een of ander leent aan iemand, broeder, zuster, mag of vriend ecu weinig rijst, dat men bij geval tekort komt. Aan het heele geval wordt waarschijnlijk niet meer gedacht, het wordt ook zelfs niet eens als leenen aangemerkt. Maar nu gebeurt het jaren later, misschien twintig, misschien nog meer, dat de betrokkenen ongenoegen krijgen, misschien zijn het zelfs hun kinderen al, en nu herinnert mon zich plotseling die vroegere leening en men eischt het geleende terug, geregeld elk jaar verdubbeld. Wanneer dan oorspronkelijk twee kommetjes rijst geleend zijn, telle men maar eens op, hoeveel dat na verloop van twintig jaar zijn kan. $N u$ kan dit ouder Christenen niet meer. Heeft men het gegevene oorspronkelijk niet als "geleend" beschouwd, dan kau men later hoogstens het dubbele van het gegevene eischen.

c. Het leenen van gelden en het vaststellen van de rente daarvan, 
moet plaats hebben in tegenwoordigheid van twee getuigen. Een zaak omtrent geleende gelden of verschuldigde rente, die niet door twee getuigen gestaafd wordt, wordt door de rechters niet aangenomen.

Ook dit artikel heeft an veel misbruik een eind gemaakt. Men hoorde toch soms de buitensporigste eischen doen omtrent gelecnde gelden en daarvoor verschuldigde procenten. Een woeker van $100 \mathrm{pCt}$. was niets ongewoons. Dikwerf was de rente in 't geheel niet bepaald, doch op een gegeven oogenblik kwam de leener eenvoudig eischen: ik moet zooveel hebben. Natuurlijk weigering om te betalen en een proces, dat dikwerf eindigde in het nadeel van den schuldenaar. $\mathrm{Nu}$ wordt in dit artikel wel niet de rentevoet bepaald, daarvoor is de Alfoersche matschappij dan ook nog niet rijp, maar het leenen kan niet meer gebeuren zoo maar, zonder meer. Het is een zaak geworden met getuigen, eu natuurlijk in tegenwoordigheid van getuigen laat men geen woekereischen hooren. Ook zou, zelfs al was een woekerrente bepaild, de rechter den eisch tot voldoening daarvan, wel afwijzen.

Heel veel komt het geld leenen van vrienden trouwens niet voor. Men helpt gewoonlijk elkaar qua familie, en hoopt dan later, in verlegenheid, ook weer geholpen te worden door wien men zelf hielp. Maar natuurlijk is er wel eens de een of de ander, die òf geen familie heeft, òf het bij zijn familie verbruid heeft en dus bij een vreemde moet leenen. Natuurlijk zijn zulke alleenstaanden ook de gemakkelijkste slachtoffers om uit te plunderen voor een woekeraar. Een lid van een groote familie krijgt men niet zoo gemakkelijk te pakken.

\section{HOOFDSTUK XVI.}

\section{OVER hET VINDEN.}

a. Wie iets vindt, zoowel op zee als op het land, moet daarvan kemnis geven aan het Hoofd van zijn kampong. Volgt hij dit gebod niet op en het wordt bekend dat hij iets gevonden heeft, dan zal hij gestraft worden, alsof hij het gevouden voorwerp gestolen had.

b. Wanneer de eigenaar van het gevondene dit terugverlangt van den viuder, moet hij dezen een geschenk geven, om zijn moeite te beloonen. Is dit geschenk niet goed in de oogen des vinders, dan kan deze de zaak aan de rechters te kemnen geven, die de grootte van het geschenk zullen bepalen.

Dit mag echter niet meer bedragen dan $\frac{1}{5}$ der waarde van het gevoudene. 
Het was wel zoowat gewoonte, dat men het gevondene teruggaf, maar toch was er niet heel sterk op te rekenen.

Het meest vindt men prauwen. Men legt die niet goed vast, of haalt ze niet ver genoeg op het strand, zoodat ze met den vloed wegdrijven. Ze worden dan drijvende gevonden en de gewoonte brengt mee, dat men zoo'n drijvende prauw meeneemt en vastlegt, wanueer men die op zee tegen komt. Echter, dit kan ook icts gevaarlijks hebben. Het gebeurt toch wel, dat lieden de prauwen, dic met cen staak vastliggen in ondiep water, bestelen en ze daarna weg laten drijven, om hun misdaad te bedekken. Vindt men nu zoo'n prauw en legt die vast, dan is het niet onmogelijk dat de eigenaar den vinder aanspreekt over hetgeen uit de prauw gestolen is, en het is dan voor dezen dikwerf moeilijk te bewijzen, dat uiiet hij de dief is. Het gebeurde daarom wel dat mijn lieden, wanneer we een prauw zagen drijven en ik wilde dat een hunner er in plaats zou nemen om haar naar den wal te brengen, eenvoudig zeiden: Mijnheer, laten we het niet doen; als we haar niet vinden, hebben we ook niet te verantwoorden wat er misschien uit gestolen is.

Anderzijds is het mij ook wel gebeurd, dat we een prauw meegenomen en vastgelegd hadden. Na eenigen tijd was die dan eenvoudig verdwenen. De eigenaar had haar meegenomen en het zelfs der moeite niet waard geacht, mij daarvan kennis te geven of te bedanken. $\mathrm{Nu}$ zou hij wellicht tegenover een Alfoer nict $z o o$ oubeschoft geweest zijn, maar het geval is toch al teekenachtig genoeg en bewijst dat alinea $b$ niet overbodig is.

\section{HOOFDSTUK XVII.}

\section{Over ONDEUGd. (NAKAL.)}

Wie eens anders goed beschadigt of vernielt moet betaleu of vergoeden, hetgeen hij vernield of beschadigd heeft, en nog daarenboven eene boete van f 0.50 tot $\mathrm{f} 16$ naar overweging der rechters.

Men verstaat heel veel onder dit Hoofdstuk. Het woord nakal is in veel gevallen weer te geven met baldadigheid, en het is ongelooflijk, hoe baldadig een Alfoer wel zijn kan.

Vooral jongelui weten met hun overmoed soms geen weg, en koelen dien op alle mogelijke manier, door vruchtboomen te beschadigen, touwen van vaartuigen door te snijden, iemands beesten dood te gooien, enz. Ook wel door 's avonds met steenen op de huizen of erven te gooien, te gaan spoken, en dergelijke. Al deze dingen vallen onder dit artikel, en ook het stelen van vruchten etc. uit tuinen, zoo het gestolene niet komt tot de waarde van f 1 . - Zie Hoofdstuk VII. 


\section{HOOFDSTUK XVIII.}

Het overtreden van gewoonten. (LANGar adat).

$a$. Wie de gewoonteu overtreedt, zal een boete betalen van f 0.50 tot f 24 naar overwegiug der rechters.

Onder dit begrip is ook heel veel saam te brengen, natuurlijk zoowel godsdienstige als maatschappelijke overtredingen. De Heiden kent geen verschil tusschen die twee, en wie dus niet voldoet aan godsdienstige wetten of gebruiken, kan evengoed gestraft worden, als hij die maatschappelijke gewoonten overtreedt. Het is naluurlijk dat men dit onk heeft willen invoeren voor het Christendom, maar ook even natuurlijk, dat het Christendom daar niets van heeft willen weten. Men zou dan eenvoudig voor elke overtreding, voor het deelnemen aan Heidensche feesten etc. gestraft worden en een boete betalen, om zich na het betaleu daarvan "rein" van elke overtreding te gevoelen, wat nogal in strijd is met het christelijk begrip "zonde."

Op maatschappelijk gebied verstaat meu er hoofdzakelijk onder allerlci zoude tegen de etiquette, het zich onvoorzichtig uitlaten tegenover Hoofden, het aanuemen van ongepaste houdingen op de rechtszitting, het niet in acht nemen van den behoorlijken eerbied voor de schoonouders, zijn huis in een andere richting bouwen dan is voorgeschreven, zich kleeden met kleedij die niet geoorloofd is, eens anders modellen namaken bij industric, de afsluiting van een tuin verbreken, door eens anders aauplant loopeu, etc. te veel om op te noemen. Gewoonlijk zijn dergelijke overtredingen licht, maar, zooals uit de boetebepaling blijkt, worden sommige ook zeer ernstig opgevat.

b. Het is ook overtreding der gewoonte, wanueer een gehuwde vrouw een andere mau volgt, of haar eigen man beleedigt door zich niet te gedragen zooals een gehuwde vrouw betaamt en ook, wanneer een man aan een gehuwde vrouw, niet den gebruikelijken eerbied bewijst.

Of een geval als het eerstgenoemde, nog onder dit artikel valt, hangt veel van de omstandighedeu af. Heeft de vrouw een man gevolgd op een eenzamen weg, dan wordt dit gewoonlijk als overspel beschouwd.

Is het echter onopzettelijk gebeurd dat zij samengingen, dan valt het ouder dit artikel. De plichten van een gehuwde vrouw zijn overigens nog al talrijk, en bij de verschillende stammen niet altijd dezelfde. De Tobèlo-Bòeng, zijn op dit punt al heel lastig. 
Maar algemeen is b.v. de gewoonte dat een gehuwde vrouw niet naast een vreemdeu man mag gaan zitten, niet in zijn prauw mag plaats nemen, hem geen diensten mag bewijzen, etc. Dikwijls ontaardt het ook wel in een soort plagerij, niet door den man zelf, maar door de schooufamilie, die hierin het middel heeft om een ongewenschte of niet-geliefde schoondochter het leven zuur te maken. De beleefdheden, die een man tegenover een gehuwde vrouw in acht te nemen heeft, zijn ook zeer talrijk, te veel om hier op te noemen.

Een gehuwde vrouw staat in hooge achting en men moet tegenover haar voorzichtig zijn, aangezien zij geldt als het eigendom harer schoonfanilie en men dus, door tegenover haar oubeleefl te zijn, haar heele schoonfamilie belcedigt. Veel van dergelijke overtredingen leiden niet tot een proces, maar men maakt de beleediging goed door 't een of ander geschenk, een traktatie, etc.

$c$. Het is overtreding der gewoonte, wanneer men een huis binnengaat, tijdens de bewoners afwezig ziju.

Meu zic hierover ook Hoofdstuk VII, over diefstal.

Wil men een huis binnengaan, dan moet men eerst verlof daartoe vragen, dat is de gewoonte. Daar men dat nu, bij afwezigheid der bewoners nict kan, is het vanzelf dat men overtreedt door binnen te gaan. Het verbod geldt echter niet de voorgaanderij, maar alleen het inwendige van de woning. Wel is het beleefd, ook tot het betreden der voorgaanderij toestemming te vragen, of te wachten tot men binnen genood wordt, maar op dat punt bestaat tot geen overtreding in den zin der adat.

$d$. Het is overtreding der gewoonte des nachts een huis binnen te gaan, en de slaapplaats eener getrouwde vrouw te passeeren.

Men moet zich hierbij ook natuurlijk de Alfoersche woningen indenken, waar men ten allen tijde heel gemakkelijk binuen treedt. Iu dezelfde ruimte slapen zoowel gehuwden als ongehuwdeu. $\mathrm{Nu}$ heeft elk huis twee ingangen, waardoor men komt in een soort gang, die men door de eene deur intreedt, door de andere uit. Die gang loopt over het middenstuk van het huis heen. Gewoonlijk doet dat middenstuk dienst als bergplaats. Langs de kanten slaapt men, de jonge meisjes en de gehuwden gewoonlijk in afgesloten, of liever, door een gordijn afgeschoten hokjes, de jonge meisjes gewoonlijk zonder zoo'u beschutting, eveuzoo de kinderen. Gaat men nu voor de woning staan, dan voert de rechtsche ingang 't eerst langs de slaapplaatsen der gehuwden, de linksche langs die der jonge meisjes. Wie nu 's nachts de woning binnenkomt gaat linksch binnen, 't zij hij een nachtelijk bezoek aan de jonge dochters 
brengen wil, 't zij hij zich bij de jongelingen neer wil leggen. Gaat hij rechts biunen, dan komt hij langs de slaapplaatsen der gehuwden; heeft dus verkeerde bedoelingen ten opzichte van eens auders vrouw en is daarom strafbaar. Of ook wel betoont hij ongepaste nieuwsgierigheid naar hetgeen er tusschen echtelieden 's nachts voorvalt en dat is niet minder strafbaar.

\section{HOOFDSTUK XIX.}

\section{Over onbeleefdheid.}

Wie onbeleefd is, betalt eene boete van $\mathrm{f} 1.60$ tot f 16 uaar overweging der rechters.

Onder "onbeleefdheid" verstaat men allerlei, b.v. het maken van onfatsoenlijke geluiden, icmand naroepen, iemand bespottelijk maken, de keel schrapen als iemand voorbijgaat, lachen achter iemands rug, kortom nog heel veel, dat wij ook niet beleefd vinden. De hoogste boete wordt natuurlijk geeischt voor onbeleeftheid tegenover hooggeplaatsten.

\section{HOOFDSTUK XX.}

\section{Over he'́ OVERLoopen van personen op de BadplaA'ts.}

a. Wanneer iemand een badplaats nadert zonder te roepen en hij treft iemand van de andere kumne nakt, zoo moet hij f 12 boete betalen.

b. Echter, wanneer do ankomende geroepen heeft en de badende niet heeft geantwoord, heeft de laatste slechte bedoelingen gehad en inoet f 12 boete betalen.

De badplaatsen zijn gewoonlijk langs de wegen. De wegen loopen over of door rivieren, en elk zoo'n overgang of doorgang doet ook dienst als badplaats. Het is nu natuurlijk noodig, dat men, ankomeude, roept om zich te vergewissen of iemand baadt of niet. Is de badende en de komende van dezelfde kunne, dan kliukt het: "kom maar", anders: "vrouw " of "man" naar de badende is. Men moet dan eenvoudig wachten, tot de badende gekleed is. Soms kan dat wachten lang duren, vooral wanneer men dicht bij een dorp komt in den vooravond, als de vrouwen zich opmaken om water te halen en zich neteen te baden.

De bepaling, alinea $b$, is er uit billijkheid bijgevoegd, omdat er wel eens personen zijı, die, belust op een avontuurtje de andere kunne laten komen. Deze wordt dan beschaamd en het gebeurde dan wel, dat de badende dan bovendien nog een klacht indiende, wegens "overloopen". Dit kan nu niet meer. Wie niet antwoordt wordt zelf boeteplichtig. 


\section{HOOFDSTUK XXI.}

\section{Over den eerbied tegenover de hoofden.}

a. Elke overtreding, gepleegd tegenover een Hoofd, zal gestraft worden met het dubbele der gestelde boete.

b. Elke overtreding tegenover het Districtshoofd zal gestraft worden met vijf maal de gestelde boete.

c. Wauneer een Hoofd zich schuldig makt an cenige overtreding, zal hij het dubbele der gestelde boete betalen.

d. Degene die weigert een bevel van zijn dorpshoofd te gehoorzamen zal gestraft worden met eene boete van f 0.50 tot f 10 . - naar overweging der rechters.

Eigenlijk ziju deze bepalingen nieuw als wettelijke bepalingen. Het is natuurlijk dat de Hoofden, als zelf rechtsprekende, overtredingen tegen henzelf gepleegd, ook nogal zwaar beboet hebben.

Het Districtshoofd eischt voor zich en de zijnen een soort onscheudbaarheid, die hij ook altijd geuoten heeft; vandaar de hooge boete. $\mathrm{Nu}$ bedenke men, dat de Hoofden vroeger nooit rechtstreeks van hun onderdauen onderscheiden waren. Zij waren rechters en leiders meer niet. Door het aanleggen van locale dorpen en het ontstaan van algemeene belaugen, is het echter noodig geworden dat zij regeerders werden en als zoodanig zich ook in stand van hun onderdanen onderscheiden. Dit zal nog wel niet zoo heel spoedig gebeuren, maar deze bepalingen zijn toch een eerste stap om daartoe te geraken.

\section{HOOFDSTUK XXI.}

\section{Over nalatigheid. (aLFa).}

Wie overtreedt door nalatigheid, zal betalen een boete van f 0.50 tot f 8.- naar overweging des rechters.

Er kan natuurlijk nog al heel wat door nalatigheid of onoplettendheid gebeuren. Men legt eens anders prauw niet goed vast en die drijft weg; men past niet goed op het vuur en er ontstaat een groote brand; men lost een schot zonder eerst de baan te onderzoeken en treft een mensch, etc. Dit alles wordt als nalatigheid beschouwd en bestraft, dus: alles wat niet opzettelijk geschiedt. 


\section{HOOFDSTUK XXIII.}

\section{Over DRONKENSCHAP.}

Overtredingeu in dronkenschap gepleegd zullen gestraft worden als waren ze in nuchteren toestand bedreven.

Dronkenschap dient dus niet als verontschuldiging, Dit is ook geheel volgens de opvattingen des volks. Gewoonlijk worden in dronkenschap geen zware misdrijven bedreven. Het bepaalt zich tot eeu scheidpartij of een vechtpartij op een feest. Het meest komt natuurlijk voor: een palmwijn roes en die is nogal ouschuldig. De menschen zijn dan wat schreeuwerig, maar daar loopt het mee af. Helaas echter wordt tegenwoordig ook veel jenever ingevoerd en daardoor komt ook onze bekende dolle woeste dronkenschap voor.

Een poos lang gold dronkenschap zelf als een misdrijf, maar spoedig kwam van den Sultan van Ternate bericht dat zulks niet mocht. Eigenlijk merkwaardig, daar die man een Mohammedaan is. Maar zijn opvatting zal wel geweest ziju, dat Hollanders en Heidenen zich gerust bedrinken mogen, daar die toch niet onder de wetten van den Koran staan.

\section{HOODFSTUK XXIV.}

\section{Over de feesten.}

Elk wic jenever of arak brengt of schenkt op een feest, moet f 10 boete betalen.

Deze bepaling is natuurlijk nieuw, en door den invoer van sterke dranken noodig geworden. Deze invoer is, tijdens het Sultanaat in zijn bloei was, verboden geweest. Op de passen der handelaren kwam voor dat het verboden was te handelen in: "arak, buskruit of eetbare vogelnestjes". Het strekt niet tot eer van het Hollandsche bewind, dat naarmate de invloeds. feer van het Gouvernement toegenomen is, aan deze bepaling steeds minder de hand is gehouden, zoodat de invoer nu zoo goed als onbeperkt is, waarvan gewetenlooze haudelaren ruimschoots gebruik maken.

Hoe het jenevergebruik werkt, kan men wel nagaan, als men bedenkt, dat de Alfoeren gewend om den palmwijn uit groote bierglazen te driuken, dit ook met de jenever doen, waarvan natuurlijk een dolle dronkenschap het gevolg is. 


\section{HOOFDSTUK XXV.}

\section{OVER KaARTSPELEN.}

Het kaartspelen om geld is verboden. Wie door de Hoofden betrapt wordt op kaartspelen, verbeurt f 3 boete.

Is hij weigerachtig die boete te betalen, dan zal de zaak voor de districtsrechtbank berecht worden.

De Alfoeren zijn uit zichzelf geen spelers. Mij is onder hen niet één kansspel bekend. Zij hebben echter door handelaren, oud-soldaten en dergelijke, het knartspelen geleerd, eerst met de Chineesche speelkanten, later ook met de gewone Hollandsche. Daar eenmaal kennis mee gemaakt hebbende, worden zij hartstochtelijke spelers, die alles op het spel zetten. Natuurlijk worden zij door de oud-soldaten enz. grof geplukt. Ik kende zoo'n sujet, dat geen cent pensioen had, maar toch als grand seigneur leefde, en van dorp tot dorp trok, om de lui aan het spelen te krijgen.

Het kaartspelen was reeds vroeger tijdens, en door het Sultansbestuur verboden. Als de adat het dus strafbaar stelde, deed zij niets, dan het reeds bestaande bestendigen. Het gaat echter moeilijk voor goed een eind aan dit ingeslopen kwaad te maken, nu de Hollanders er zich zoo gaarne aan schuldig maken. Er lag eens op de reede van Tobèlo een oorlogsschip. Des avonds waren we de gasten van heeren officieren. Mijn roeiers hadden ons met de prauw opgewacht en ik hoorde ze dadelijk den volgenden dag met elkaar er over praten dat wel hun het spelen om geld verboden was, maar de officieren aan boord dien geheelen avond onafgebroken om zilvergeld gespeeld hadden! Kwaad kon het dus niet zijn, nu de Hollanders het zelf deden.

\section{HOOFDSTUK XXVI.}

\section{OVER HE'T JACHTRECH'T.}

Wauneer men een dier vindt of doodt, dat reeds aangeschoten of opgejaagd is door anderen, zal men het met hen die het aanschoten of opjaagden, gelijkelijk deelen.

Het is natuurlijk, dat ook deze regel niet altijd gevolgd wordt. Ook is het dikwerf moeilijk te bewijzen, of een geschoten dier 't zelfde is, wat anderen reeds aangeschoten hebben. Is het geval echter duidelijk, dan makt niemand bezwaar zich naar dezen ouden regel te gedragen.

7• Volgr. IX. 


\section{HOOFDS'TUK XXVII.}

\section{Over hET zETTEN VAN vOETANGeLs.}

a. Het is verboden voetangels te stellen tot het vangen of dooden van dieren.

b. Wie dezelve stelt zal f 3 boete betalen, en wanueer er iemand getroffen (gedood) wordt, zal de steller veroordeeld worden wegens moord.

c. Rondom cen tuin mogen voetangels gesteld worden, van des avonds tot des morgeus (gedurende den nacht), maar niet, dan met plaatsing van de gewone teekens, en het kenuis geven aan het kamponghoofd en an de lieden, wier tuinen in de buurt liggeu, vau den aldus omstelden tuin.

Voor hetgeen hier bedoeld wordt, is in het Hollandsch moeilijk een woord of een juisten naam te vinden. Men tracht dieren te dooden door vernuftige toestellen, die bij aanraking een pijl doen gaan in het voorwerp, dat ze aantrekt. Voor herten worden ze wat hooger gesteld, voor varkens lager. Deze zijn wel te onderscheiden van strikken die men ook gebruikt, maar die niet gevaarlijk zijn voor menschen. $\mathrm{Nu}$ is het gewoonte dat men, dergelijke diugen in een bosch stellende, dat te kennen geeft, door het hangen van een zeker soort bladen rondom de onveilige plek. Men kan zich dan dus wachten. Dit gaat nu echter goed diep in de bosschen, waar 's nachts nooit iemand komt, omdat er geen tuinen zijn en die dus uitsluitend het eigendom zijn van den jager. Daar is het zonder gevaar en daarover handelt ook het verbod niet. Het betreft de plaatsen in de buurt der dorpen, waar alles vol tuinen is en dus de boschpaden heel veel betreden worden.

Daar zijn ze gevaarlijk, ook zelfs al zijn ze van teekens voorzien. Want hoe licht is het mogelijk, dat de een of ander niet over het gewone pad gaat, maar zich door het bosch beweegt, om hout te kappen etc.

Daarom vond men goed, het stellen van dergelijke gevaarlijke dingen te verbieden. Echter, men heeft in de tuinen dikwijls veel last van ongedierte en dus vond men goed, dat elk zijn eigendom des nachts kan beveiligen, maar nog alleen met de in alinea $c$ genoemde voorzorgsmantregelen.

\section{HOOFDSTUK XXVIII.}

\section{Over vischrecht.}

a. Men mag in open zee visschen met den hengel, de lijn of de elger, waar men zulks slechts wenscht. 
Wil men visschen met het werpnet of treknet voor een vreemd dorp, dan moet men daartoe eerst verlof vragen aau het Hoofd vau dat dorp.

b. Met de zegen (gioep) mag men niet visschen, iudien niet het hoofd en de bewoners van het dorp, waartegenover men het net uitgooit, dit goed vinden.

Vroeger hebben dergelijke bepalingen niet bestaan. Dit lag ook in den aard der zaak. Men woonde tezamen op de hoofdplaats, en ging van daar visch zoekeu, waar men zulks slechts wenschte.

$N u$ echter woont men in locale dorpen, en het is natuurlijk dat de bewoners van een dorp niet willen, dat de visch die door hen soms in de een of andere bocht voor 't een of andere dorp met een bepaald doel voor een poos niet gestoord werd, door een vreemde wordt weggevischt. Er blijven altijd nog genoeg onbewoonde plaatsen en eilanden, waar men vrijelijk visschen kan.

Wat alinea $b$ betreft, hier is sprake van een groot sleepnet, waarmede men op de hariugvangst gaat. De visch zwemt in scholen. en wordt op zekere tijden gezien, als wanneer ze dicht onder den wal zwemt, misschien wel met het oog op 't kuitschieten. Men maakt er jacht op met kleine sleepnetten, ook met slaguetten, maar krijgt dan toch slechts een gedeelte van een school in zijn macht. Met de zegen wordt echter een heele school in eeus weggevischt, en dat schijut het uitsterven van die vischsoort ten gevolge te hebben.

Ook is het natuurlijk dat de bewoners der dorpen er niet op gesteld zijn, indien zoo'n groote slokop alles voor hun neus wegvangt.

Het wordt nu gewoonlijk zóó gevonden, dat een eigenaar van een zegen met de bewoners van een dorp, waarvoor hij zijn net wil uitgooien, overeenkomt, dat de lieden hem volgen zullen als helpers, en daarvoor een aandeel in den rijken buit krijgen.

\section{HOOFDSTUK XXIX.}

\section{Over het VERNIELEN VAN EIGENDOMMEN DOOR DIEREN.}

a. Indien iemands dieren eigendommen van anderen vernielen, moet de eigenaar der dieren de schade vergoeden.

$b$. Indien dit ten tweeden male gebeurt, heeft degene, wiens eigendom vernield is, het recht de dieren te dooden, maar niet, zonder van zijn voornemen eerst kennis te geven san den eigenaar der bewuste dieren. 
Een dergelijke bepaling mag vrecund klinken voor een volk, dat geen veestapel heeft, maar men heeft honden en kippen. De laatste zijn nogal onschadelijk, want in den tijd van het rijstplanten houdt men ze uit eigen belang wel vast of ruimt ze op. Maar erger is het met de houden. Sommigen houden er heele troepen van op na, maar niemand denkt er ooit aan, ze eten te geven. Het gevolg is, dat ze eten gaan zoeken, en uit honger, allerlei cten wat een hond gewoonlijk niet zou eten. Een maisveld b.v.b. is van hun gading, en het gebeurt meer dan eens, dat de een of ander een zeer mooien tuin met mais heeft, maar 's morgens daar niets meer van viudt, daar een troep honden 's nachts alles opgepeuzeld heeft. Om dit tegen te gaan, dient dit artikel. Men was toch vroeger al tamelijk weerloos in zoo'ı geval. Op de beesten passen gaat niet. Schoot of sloeg men ze dood, dan volgde gewoonlijk een klacht van den eigenaar der honden om schadevergoeding, en gewooulijk moest dan de beschadigde ook nog boete betalen, niet eens weinig!

\section{HOOEDSTUK XXX.}

\section{Over he't BIJ'TEN VAN MENSChEN DOOR DIEREN.}

$a$. Indien een hond iemand bijt, zal de eigenaar van den hond eene boete betalen van f 1.60 tot $\mathrm{f} 32$ naar overweging des rechters.

b. Wanneer iemand gebeten wordt des nachts, dicht bij iemands huis, of des daags bij het willen binneugaan van een huis welks eigenaar niet aanwezig is, heeft zoo iemand dat zichzelf te wijten.

In gewone gevallen heeft over het bijten van een hond geen aanklacht plaats. Het oude recht zegt, dat degene, wiens hond iemand bijt, zorgen moet de woud te doen genezen; hij moet de wond dus zelf medicineereu, of de kosten van de behandeling dragen.

$\mathrm{Nu}$ komt het echter voor, dat een ongehoord hooge rekening wordt ingediend voor dat medicineeren, en dan volgt een moeilijke rechtszaak. Dit kan nu niet meer bij de Christenen. Men kan klagen, en de boete krijgen, die natuurlijk naar omstandigheden geregeld wordt, niet zoozeer naar de grootte der wond, dan wel naar de omstandigheden waaronder de verwonding plaats vond.

Men let er sterk op, of de hond bijterig van aard was, in welk geval de eigenaar bijzonder strafschuldig is; of de eigenaar den hond heeft teruggeroepen, dan wel heeft aangehitst, etc.

Het betalen der medicijnen, of der geneeskundige behandeling, acht men geen straf meer, aangezien zich elk kosteloos door den Zendeling of door de Inlandsche helpers kan laten medicineeren. 


\section{HOOFDSTUK XXXI.}

Over eigendumsrech't.

De gewoonte dat, indien twee personen een rechtszaak hebben over het bezit van een voorwerp of een stuk land, degene welke in het gelijk gesteld wordt, een zekere som moet betalen voor zijn eigendomsrecht, wordt zoodanig veranderd, dat in dergelijk geval de verliezer de gerechtskosten te betalen heeft.

Dit is ook al een bijzonder onrechtvaardig gebruik, natuurlijk niet uit het volk voortgekomen, maar door de Ternataansche Hoofden ingevoerd.

Iemand heeft b.v. een boom. Een ander makt er aanspraak op. Wil hij nu zijn eigendomsrecht handhaven, dan moet hij de zaak voor het gerecht brengeu. Wordt daar nu eene, voor hem gunstige uitspraak gedaan, dan moet hij een, dikwijls aanzienlijke som, betalen aan de rechters. Doet hij dit niet, dan wordt de zaak niet ten zijnen nadeele beslist, d. w. z. zijn tegenpartij wordt niet in het gelijk gesteld, maar de Hoofden nemen eenvoudig zelf bezit over het betwiste eigendom.

De zaak is nogal duidelijk: De Hoofden wilden wat trekken, de verliezer had niets, de winner wel, ergo moest die meer betalen.

Men behoeft niet te vragen, tot hoeveel ongerechtigheid deze bepaliug al aauleiding gegeven heeft. Had iemand iets, dat begeerlijk was in de oogen der Hoofden, dan werd hem eenvoudig door de een of ander het bezit daarvan betwist. De rechtszaak werd dan ten zijnen voordeele beslist, maar de Hoofden eischten zulk een hooge eigendomsom, dat de man niet kon betalen, en de bezitting dus aan hen kwam. Weer anderen zagen zich het bezit van 't een of ander op de brutaalste manier betwist, maar gingen maar liever tot een schikking over met den aaurander, dan tot een rechtszaak, gedachtig aan het halve ei en den leegen dop. Aan dergelijke praktijken makt dit artikel een einde.

\section{HOOFDSTUK XXXII.}

\section{Over rechtspraAK.}

a. Elk heeft zijn rechter in eersten aauleg in zijn kamponghoofd.

$b$. Het is een ieder verboden, een zaak te brengen voor een ander, dan zijn kamponghoofd.

Ook deze artikelen ziju ontstaan uit den nieuwen toestand. 
Vroeger had men geen hoofden van locale dorpen, maar stamhoofden. Elke rechter was toen zijn stamhoofd. Nog lang was men geneigd, een zaak eenvoudig te doen berechten door een of ander Hoofd, waarmede men verbonden was door banden des bloeds of der vriendschap. Hierop ziet deze alinea.

c. Indien een dorp bestuurd wordt door meer dan één Hoofd, zullen dezen te zamen rechtspreken.

In grootere dorpen heeft men een dorpshoofd (kimalaha) en een dorpsoudste (mahimo). Het gebeurde nogal eens, dat deze twee waardigheidsbekleeders, in plaats van te zamen het recht te handhaven dit ieder op eigen gezag deden, en niet ten voordeele van het recht zeer sterk met elkaar concurreerden.

d. Wanneer de dorpshoofden het niet cens zijn over eenige zaak, kan elk hunner een hoofd van een naburige kampong roepen als bijzitter.

$e$. Indien er eenige zaak is tusschen bewoners vau verschillende dorpen, moet die zaak onderzocht en berecht worden door de gezamenlijke Hoofden der dorpen waarin partijen wonen.

$f$. Alleen Hoofden mogen rechtspreken, en moeten dit doen volgens de adat der christenen, zooals die in dit boek beschreven is.

De eerste zinsnede van artikel $f$ mag vauzelfsprekend zijn, doch is het toch lang niet voor Alfoeren. Vroeger heeft men bij rechtspraak geen Hoofden noodig gehad. De zaken ziju onderling berecht, onder voorzitterschap van een oude of aanzienlijke, of wel een brutaal heer met grooten mond. Kon men het over de toepassing van de adat niet eens worden, dan pas wendde men zich tot een Hoofd om dezen te laten beslissen. Ook nu wil men zich nog wel aan die gewoonte houden en dus zijn zaken laten berechten door menschen, die daartoe niet gerechtigd zijn. Dat was nu nog niet zoo erg, als dergelijke lui dienst deden als vredemakers, maar daarom is het hen niet te doen. Het uitgesproken vonnis bestat in een geldboete, en die komt voor de helft an den rechtspreker, en daar gaat het dus om.

g. Van alle zaken, die in den loop van een maand door een kamponghoofd berecht zijn, moet hij aan het eind der maand kenuis geven an het Hoofd der districtsrechtbank.

Dit is het districtshoofd (de Sangadji) of thans de vertegenwoordiger van het Europeesch gezag. De bepaling is natuurlijk gemaakt, opdat dat Hoofd op de hoogte zou blijven van wat er iu het district voorvalt.

h. Alle boeten voor groote zakeu (bedragende meer dan f 8.-) moeten betaald worden aan het Hoofd van de districtsrechtbank opdat 
deze, aan het eind van elke drie maanden, die boeten verdeele onder de verschillende Hoofden, naar elks aanspraken.

Over de verdeeling der boeten, zie Hoofdstuk XXXIV.

$i$. Wie zich niet neer wil leggen bij de beslissing van een kamponghoofd, kan zijn zaak voor de districtsrechtbank brengen, maar hij moet dan eerst de boete betalen, door het kamponghoofd opgelegd.

Is dat niet gebeurd, dan neemt de districtsrechtbank de zaak niet aan.

De districtsrechtbank zal ook geen zaken aannemen, die nog niet door het Hoofd der kampong, waarin de zaak voorgevallen is, zijn onderzocht.

In de districtsrechtbank moeten zitting hebben de Hoofden der kampongs, wier onderdanen terecht staan.

Was de eerste bepaling van dit latste artikel er niet, er zou nooit iemand in zijn vonnis berusten. Alfoeren zijn bijzonder proceslustig. Hun grootste genoegen is, naar een rechtspraak te gaan. Moet men nu echter beginnen met te voldoen wat het kampongshoofd oplegt, dan vermindert daardoor de twistlust al zeer veel, want het is er toch om te doen er zonder kleerscheuren af te komen. Vroeger legde zich zoowat nooit iemand bij een rechterlijke uitspraak neer. Elk wilde gelijk hebben, dus de in het ongelijk gestelde partij betaalde niet, maar zocht het hoogerop. Dit is nu wel zoowat belet. Natuurlijk dat de betaalde boete teruggegeven wordt, zoodra ten onrechte betaald is. Is die terecht betaald, dan moet ook de districtsrechtbank voor hare moeite betaald worden, en men gaat daar dus niet zoo spoedig meer heen met onbillijke zaken als vroeger.

$j$. Kamponghoofden mogen geen zaken berechten, welker boeten hooger zijn dan f 8.- Zaken met hoogere boeten moeten door de Hoofden der kampongs, waarin de zaak voorvalt worden onderzocht, maar door de districtsrechtbank berecht.

Hieruit zou kumnen ontstaan, dat inhalige kamponghoofden de zaken laag beboetten, alleen om die boete voor zich alleen te houden, maar dit wordt eerstens belet door de bepaling artikel $g$, dat het districtshoofd kennis moet krijgen van de zaken die door de kamponghoofden berecht worden. Komen ze hem voor te laag beboet te zijn, dan laat hij ze natuurlijk voor zich brengen; ten tweede wordt dit belet door artikel $i$, slotbepaling, dat de kampoughoofden zitting moeten hebben als de zaken van hun onderdanen berecht worden, waardoor ze dan ook aanspraak krijgen op een gedeelte der boeten. 


\section{HOOFDSTUK XXXIII.}

OVER EEDZWEREN EN VALSCHELIJK ZWEREN.

a. Wanneer iemand een ander beschuldigt van eenige overtreding zonder getuigen bij te brengen, en de beschuldiging door den beschuldiger volgehouden wordt, nietfegenstaande de beschuldigde die lochent, zoo kan de beschuldigde zich van de beschuldiging reinigen door een eed.

Daartoe zal de beschuldigde door zijn Hoofd voor den Zendeling gebracht worden. De Zendeling zal hem wijzen op het gewicht van de eed, en wanneer hij, niettegenstaande dat, bij zijn voornemen blijft, zal de Zendeling hem de eed afnemen, volgeus de formule in artikel $c$.

De beschuldiger zal nu ecu boete wegens laster betaleu, overeenkomende met die, welke de beschuldigde had moeteu betalen voor het vergrijp, waarvan hij beschuldigd was.

b. Mocht later blijken, dat valschelijk gezworen is, dan zal degene die de valsche eed aflegde, f 48 boete betaleu en de rechters zullen de boete, door den beschuldiger betaald wegens laster, aau hem terug betalen.

c. Bij het afleggen van de eed, zal men de linkerhand op den geopenden Bijbel leggen, van de rechterhand drie vingers omhoog steken, en de volgende woorden in de landstaal uitspreken:

"Wat ik zeg is waar, God zij mijn getuige; indien ik lieg kome zijn zegen niet op mij, dat zweer ik."

Zooals hieruit blijkt, is de zuiveringseed de eenige eed die gezworen wordt. Dit is reeds van oudsher zoo geweest.

Natuurlijk dat de overgang tot het Christendom ook het verlaten van de oude eed meebracht. De zorg toch voor de Heidensche eed is in handen der stamvaders, die moeten er op toezien. Met het vervallen van het geloof aan de macht dier dooden, vervalt ook de eed. Echter, men kan die nu eenmaal niet missen. Het rechtsgevoel des volks eischt die. Een boete voor valsch zweren, heeft vroeger niet bestaan. Wel heeft men, in geval de eed valsch bleek te zijn gezworen, de boete wegens laster teruggeëischt. Maar het volksgeloof maakte die boete ook overbodig. Wie valschelijk zwoer werd getroffen door de wrank der geesten. Die wraak werd afgeleid uit onheilen, die zoo iemand treffen. Had dus iemand gezworen, en hem treffen later onheilen, dan werd hij dadelijk aangeklaagd, en aangemaand de laster-boete terug te betalen, omdat hij 
valsch gezworen had. Bleef zoo iemand dan toch bij ziju houding dan volgde daaruit een proces en het was geen wonder zoo de rechter uit de onheilen, die zoo iemand treffeu, eenvoudig concludeerde tot een valsch gezworen eed. Toch was dit onrecht. Had de man werkelijk valsch gezworen, dan had hij dit al wel toegegeven bij het eerste onheil dat hem getroffen had, want hij zou dan daarin dadelijk zelf de wraak der geesten gezien hebben.

De beschuldigingen toch betroffen gewoonlijk overspel en werden door nijdige lieden gehaald uit de onbeduidendste feiten, vooral door jaloersche vrouwen.

$\mathrm{Nu}$ is het duidelijk, dat op het oogenblik de eed, op christelijke wijze gezworen, nog niet veel hooger staat dau die welke vroeger op oud-Heidensche wijze gezworen werd. Maar men is er toch banger voor. Men bedenke toch, dat onder de Heidenen ook veel lieden voorkomen, die tamelijk sceptisch gezind zijn tegenover het ond-Vaderlijke geloof en de geesten, en die dus niet veel om een eed geven. Nu komt echter de christelijke eed. Het geloof daaraan is nog ongeschokt. Het kwam meermalen voor dat lieden met alle genoegen zweren wilden, maar dan op Heidensche wijze. Werd hen echter gezegd, dat zij, als Christenen het ook op Christelijke wijze moesten doen dan krabbelden zij terug. Daar wagden zij zich niet aan. Eenmaal kwam een jonge man voor me; het districtshoofd verplichtte hem tot de eed, aaugezien hij door een vroeger meisje van hem beschuldigd werd vau overspel. Hij had n.l. in plaats van dat meisje een ander getrouwd; dat was in haar oogen onvergeeflijk en dus beweerde zij dat hij haar eens lang geleden, op cen eenzamen weg gemolesteerd had. De man zwoer, on daarmede was de zaak uit, maar hij eischte nu ook van zijn tegenpartij de boete wegens laster. Het districtshoofd bepalde dat die boete over drie maanden betaald zou worden, als voor dien tijd niet gebleken was, dat de eed valsch was gezworen. Hierbij moest de man zich neerleggen. Echter, juist ééu dag vóór dien termijn hakt hij zich in zijn been, en krijgt een zware wond. De boete werd nu niet betaald. 's Mans vrouw is overtuigd van zijn schuld, en wil van hem scheiden. Doch hij geneest weer, en de vrouw laat zich bepraten bij hem te blijven. Hij gaat op reis, en na een poosje sterft hun kind. Nu laat de vrouw zich door niets weerhouden haar mau te verlaten die kennelijk valsch gezworen had. Het was voor haar volkomen duidelijk. De geest van de krachtige christelijke eed had eerst getracht den man zelf te dooden, maar nu dit mislukt was, had hij zich op het zwakkere kind geworpen, en dit was gemakkelijk zijn prooi geworden!

d. Eeden, niet op die voorschreven wijze voor den Zendeling afgelegd 
zijn onder Christenen niet van kracht, en daarvoor mag ook geen betaling (o koboto ma hohoko) geëischt worden.

Dit beduidt de afschaffing van een leelijke gewoonte, $\mathrm{nl}$. om zichzelf te vervloeken of te bezweren, vooral met het oog op het huwelijk van dochters, om daar later winst uit te kloppen.

Een vader of moeder hoort, dat de een of ander het oog op hun dochter heeft geslagen, worden daar nu heel boos over en doen een eed, dat zoo iemand nooit in huu huis komen zal, nooit hun dochter trouwen zal, etc. Het is natuurlijk meer eene vervloeking dan cene eed die bij zulk een gelegenheid gebruikt wordt. Er is nu geen sprake van, dat het huwelijk niet zal doorgann, maar op den bruidsschat moet nog f 10 extra gelegd worden om die eed af te koopen; zulks is de "vrucht van de eed", het gevolg van de eed, al naar men wil. Anderen zweren maar heel gewoon, dat hun dochter nooit trouwen zal, waarmede zij van de f 10 verzekerd zijn.

Dat gebruik nu, wordt onder Christenen door artikel $d$. afgeschnft.

\section{HOOFISTUK XXXIV.}

\section{OVER HET BETALEN EN VERDEELEN DER BOETEN.}

a. De rechter zal een zekeren termiju stellen tot het betalen der boeten. Wanncer iemand binnen den gestelden termijn zijn boete niet betaalt, hebben de Hoofden het recht zooveel van zijn goederen te nemen, dat daardoor de boete en de moeite van het Hoofd betaald kunnen worden.

Gewoonlijk behoeft niet op deze wijze boete geïnd te worden. Het betalen van een boete is een soort eereschuld, waaraan de heele familie meehelpt. Dit is ook natuurlijk. De boete is de verzoening voor de beleedigde adat. Zoolang die niet betaald is staat men aau de wraak der geesten bloot, tenminste van Heidensch standpunt bezien.

Vertrouwt het districtshoofd de zaak niet, dan houdt hij den schuldige eenvoudig gevangen, totdat de boete voldaan is.

$b$. Alle boeten zullen verdeeld worden tusschen de rechters en den aanklnger volgens de gewoonte.

De gewoonte is, dat de rechters en de aanklagers in strafzaken gelijkelijk opdeelen. Onder de Hoofden krijgt natuurlijk het districtshoofd het leeuwendeel, de andere Hoofden naar mate van hun rang. Het immoreele van dit stelsel valt natuurlijk dadelijk in het oog. De Hoofden leven aldus vau de misdaden van het volk. Het is meer dan eens voorgekomen, dat Hoofden 
zelf tot misdaden aanzetten, om ze daarna te beboeten en zich te verrijken. In den laatsten tijd wordt een groot gedeelte der boeten in de distriots- of negorij-kas gestort. Of nu de Hoofden ook uit die gelden bezoldigd worden geloof ik niet. Men bedenke dat de kamponghoofden hier allen onbezoldigd zijn en dus het aandeel der boeten hun eenige bezoldiging uitmakt. In elk geval staat het stelsel, om maar raak hooge boete op te leggen tot stijving van een uitgeputte negorij-kas moreel niet veel hooger dan het vroegere. Het boetestelsel werkt in zijn geheel onder volken als de Alfoeren demoraliseerend, en men moet er hoe eerder hoe liever voor goed mee breken.

c. De boeten voor het niet opvolgen vau de bevelen van een Hoofd, komen dit Hoofd zelf ten goede.

Natuurlijk, hij is in dit geval immers klager en rechter beide.

d. Wanueer een zaak zonder boete wordt beslist, maar de rechter de partijen bevredigt, moet degene, die in het ongelijk gesteld is, de gerechtskosten dragen.

Dit heet in het Maleisch : "alas kadèra", "stoelbekleeding". Het bedraagt van f $1 .-$ tot f $3 .-$ en is het loon voor de rechters.

$e$. Bij een rechtzaak over iets dat vernield is, over schuld, bruidsschatten, erfenissen, eigendomsrecht enz. zullen de rechters $\frac{1}{1} \overline{0}$ ontvangen vau de som die door hun vomnis verschuldigd is.

Eene opmerking ten slotte. Wanneer men de vraag stelt, of nu altijd volgens de adat recht gesproken wordt? dan moet het antwoord luiden: $W e l$ voor zooverre recht gesproken wordt door inlandsche Hoofden, helaas dikwerf niet, waar recht gesproken wordt door Gouvernementsambtenaren. Voor dezen schijnt het soms een groot genot, nu zelf eens te kunnen uitmaken wat recht is, en aangezien de rechtspraak hier nooit gecontroleerd wordt, kan men aan die liefhebberij oubevreesd toegeven. Men ziet echter daarbij over het hoofd, hoe bedenkelijk het is volken als deze een recht voor te schrijven dat geen verband houdt met het eigen rechtsgevoel. Men verkracht daardoor het rechtsgevoel des volks en demoraliseert het. Of dan verkeerde begrippen ongewijzigd moeten blijven bestaan? Neen, maar men wijzigt die niet door ruw ingrijpen, wel door opvoeding. Met die noodige opvoeding der volken belast zich de Zending en kan mijus inziens nooit anders dan in het belang der 
Regeering zijn, zoo zij de Zending met deze haar taak stil laat begaan.

Mag dan de Zeuding wetgevend optreden? Dat doet zij niet, heeft zij nooit gedaan, en zal zij nooit doen. Maar zij wil een zuurdeeg zijn, dat de volken doortrekt, opdat zij leeren het goede te willen. Men zij slechts niet jaloersch op haar, zij is niet gevaarlijk voor de Regeering, al kan haar werk wel eens onaangenaam zijn voor den een of anderen ambtenaar, hoewel nooit voor dengenen die werkelijk het goerle zoeken voor de volken die zij geroepen worden te besturen. Men erkenne het onbaatzuchtige van het streven der Zending; steune haar, of, voor het minst, belette haar niet haar taak tot heil der volkeren te volvoeren!

September 1908 . 